\title{
Late Miocene to Pliocene stratigraphic evolution of northeast Carmen Island, Gulf of California: implications for oblique-rifting tectonics
}

\author{
Rebecca J. Dorsey ${ }^{\mathrm{a}, *}$, Paul J. Umhoefer ${ }^{\mathrm{b}}$, James C. Ingle ${ }^{\mathrm{c}}$, Larry Mayer ${ }^{\mathrm{d}}$ \\ ${ }^{\mathrm{a}}$ Department of Geological Sciences, 1272 University of Oregon, Eugene, OR 97403-1272, USA \\ ${ }^{\mathrm{b}}$ Department of Geology, Box 4099, Northern Arizona University, Flagstaff, AZ 86011, USA \\ ${ }^{\mathrm{c}}$ Department of Geological and Environmental Sciences, Stanford University, Palo Alto, CA 94305-2115, USA \\ ${ }^{\mathrm{d}}$ Department of Geology, Miami University, Oxford, OH 45056, USA
}

Received 1 November 1999; revised 10 June 2000; accepted 20 July 2000

\begin{abstract}
This paper describes a thick section of upper Miocene(?) to middle Pliocene marine sedimentary rocks exposed at Punta Perico, northeastern Carmen Island, in the southern Gulf of California. These strata overlie Miocene volcanic rocks along a lowangle unconformity and have a total thickness of $\sim 1100 \mathrm{~m}$. The section contains the following units: (1) lower conglomerate ( $\sim 750 \mathrm{~m}$ thick) representing submarine debris flows and grain flows; (2) conglomerate and sandstone ( $\sim 90-160 \mathrm{~m})$ deposited by gravelly grain flows and sandy turbidity currents; (3) marlstone and mudstone $(\sim 120 \mathrm{~m})$ with benthic forams that record bathyal water depths $(400-500 \mathrm{~m})$ and an age of $\sim 3.5-3.1 \mathrm{Ma}$; (4) dacite breccia and boulder beds $(\sim 20 \mathrm{~m})$ emplaced by submarine avalanches and debris flows and (5) stratified conglomerate and bioclastic limestone ( $\geqq 80 \mathrm{~m}$ ) deposited by traction currents in a shallow shelf environment. Conjugate syn-sedimentary faults, deformation bands, and growth structures are recognized within a 250-m-wide belt adjacent to a large $\mathrm{N}$-striking, W-dipping normal fault that bounds the eastern margin of the Pliocene section, indicating that the eastern normal fault was active during deposition of at least the upper $\sim 300 \mathrm{~m}$ of the dipping section. Considering the thickness of the two units below the marlstone $(\sim 900 \mathrm{~m})$ and assuming a range of possible sediment-accumulation rates $(0.2-1.0 \mathrm{~m} / \mathrm{ka})$, we postulate that deposition of the lower conglomerate was initiated in late Miocene or early Pliocene time ( $\sim 8-4 \mathrm{Ma})$, possibly coincident with initial opening of the Gulf of California. Deposition of the marlstone unit above a probable unconformity represents a major change in basinal tectonics at $\sim 3.5-3.1 \mathrm{Ma}$, which is about the time when seafloor spreading and transform faulting were initiated in the Gulf of California. These tentative correlations suggest that the Baja California peninsula was structurally and mechanically linked to the deep Gulf during late Miocene to middle Pliocene time. (C) 2001 Elsevier Science B.V. All rights reserved.
\end{abstract}

Keywords: Pliocene; Gulf of California; Stratigraphy; Micropaleontology; Tectonics

\section{Introduction}

\footnotetext{
* Corresponding author.

E-mail addresses: rdorsey@darkwing.uoregon.edu (R.J. Dorsey), paul.umhoefer@nau.edu (P.J. Umhoefer), ingle@pangea.stanford.edu (J.C. Ingle), mayer1@muohio.edu (L. Mayer).
}

The Gulf of California is a highly oblique-divergent plate boundary that has evolved in the past $\sim 6$ million years into a young ocean basin that is opening along well developed transform faults connected by short 


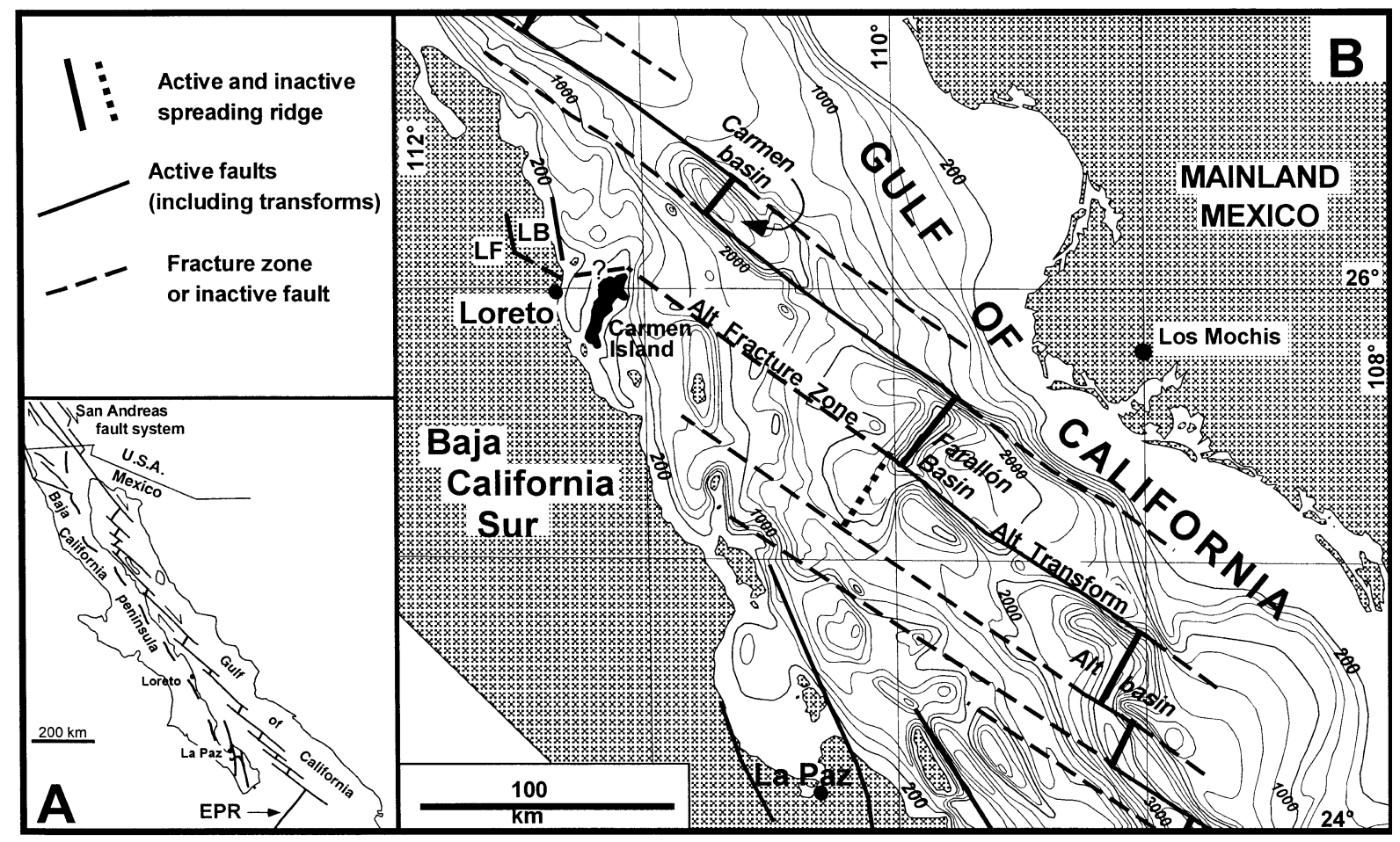

Fig. 1. (A) Regional tectonics of the Pacific-North America plate boundary in the Gulf of California. (B) Bathymetry and major structures in the southern Gulf of California, showing oceanic transforms, spreading centers, fracture zones, and fault-bounded blocks in the shelf region between Baja California and the deep gulf. EPR = East Pacific Rise; LF = Loreto fault; LB = Loreto basin.

spreading ridges (Fig. 1; Moore and Buffington, 1968; Larson et al., 1968; Curray and Moore, 1984; Lonsdale, 1989). The first stage of major offset in the gulf took place along a system of strike-slip faults and related pull-apart basins oriented parallel to the overall gulf trend between $\sim 6$ and $3.6 \mathrm{Ma}$ (Lonsdale, 1989). Beginning $\sim 3.5 \mathrm{Ma}$ this fault zone evolved into the modern system of transform faults oriented $\sim 20^{\circ}$ more westerly than the gulf trend, and it is generally believed that most of the Pacific-North America plate motion since $3.5 \mathrm{Ma}$ has occurred on transform faults and linked spreading centers in the deep gulf (Lonsdale, 1989; DeMets et al., 1990; DeMets, 1995). Recent work in the Loreto area has provided useful information about the timing and style of late Pliocene transtensional deformation and basin development in eastern Baja California Sur (Fig. 1B; Umhoefer et al., 1994; Zanchi, 1994; Umhoefer and Stone, 1996; Umhoefer and Dorsey, 1997), but structural relationships and connections between the onland faults and oceanic transforms in the gulf are complex and remain poorly understood.

Pliocene geology and stratigraphy exposed on Carmen Island permit us to study the history of deformation and sedimentation within the narrow shelf region that lies between the continental microplate of Baja California and young oceanic transforms and spreading centers in the Gulf of California. The continental shelf in the southwestern gulf displays steep irregular bathymetry controlled by large fractures zones, believed to be inactive (Lonsdale, 1989), and younger strike-slip and normal faults that bound linear crustal blocks and island uplifts (Fig. 1B). The presence of raised marine terraces around the margins of the island and a small platform of flat-lying Pleistocene carbonates exposed up to $\sim 20 \mathrm{~m}$ above sea level on the southern peninsula (Fig. 2A), combined with its overall linear geometry and steep flanking bathymetry, all suggest that Carmen has been uplifted during late Pliocene(?) and Pleistocene time by young ENE-striking normal 


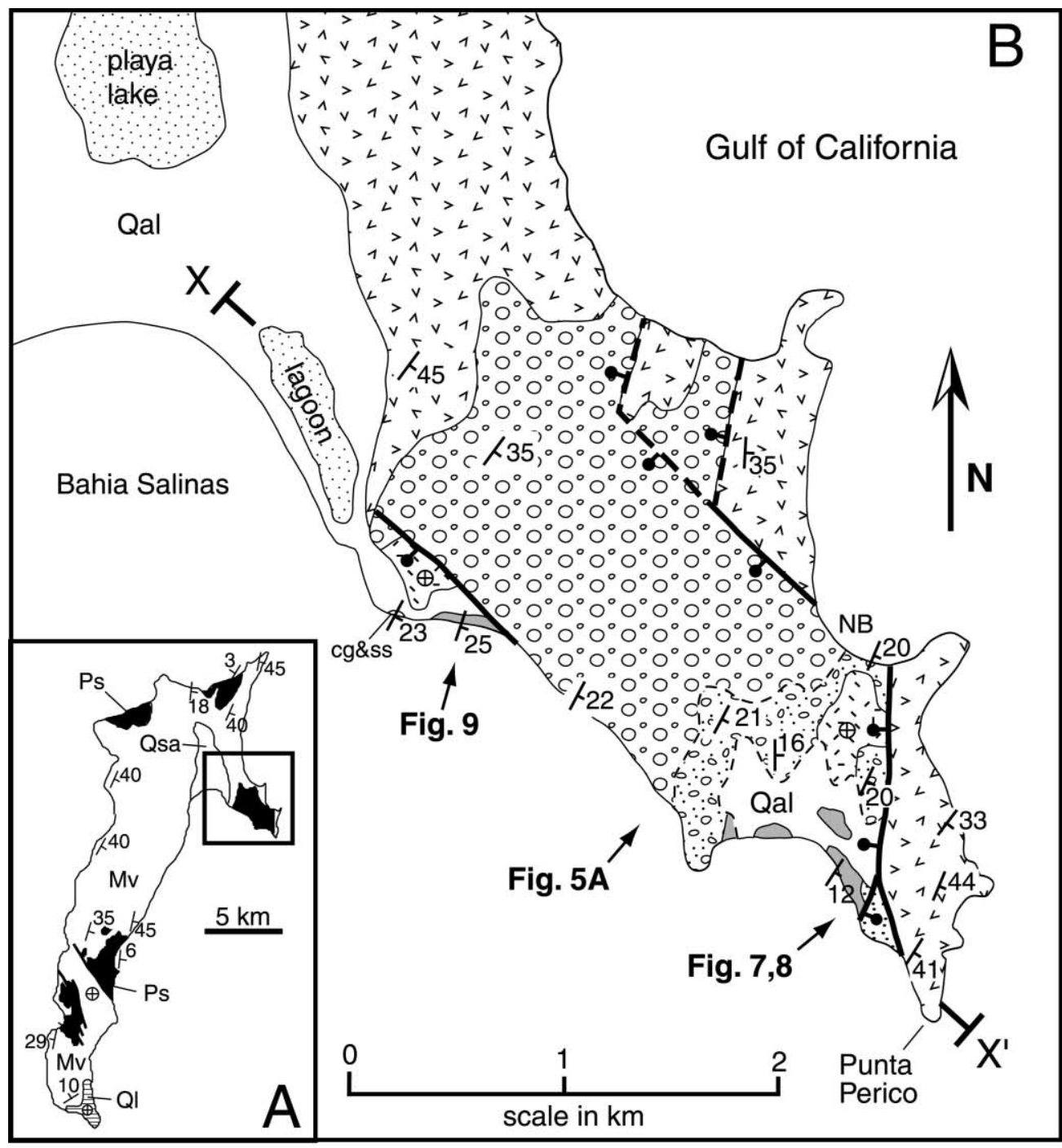

\section{EXPLANATION}

\section{$\because: 0: 0$ Pliocene conglomerate and sandstone}

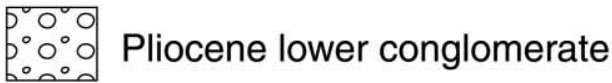

$\vec{r}>>1$ Miocene volcanic rocks

\section{Qal Quaternary alluvium}

$\therefore$ Plio-Pleistocene (?) sandy calcarenite

Plioc. upper conglomerate and bioclastic limestone

Pliocene marlstone and mudstone

Fig. 2. (A) Simplified geologic map of Carmen island, modified from Anderson (1950) and unpubl. field data. Mv is Miocene volcanic rocks; Ps is Pliocene sedimentary rocks; Q1 is Quaternary limestone; Qsa is Quaternary salt and alluvium in the north Carmen salt graben. (B) Geologic map of the area between Salinas Bay and Punta Perico. Mapping for this study was carried out by the authors on a combined topographic and Landsat image base. Heavy lines with bar and ball are normal faults. $X-X^{\prime}$ is the line of section in Fig. 3 . NB $=$ north beach (informal name). Strike and dips in A and B represent bedding attitudes. 
faults on the east and west margins of the island. The bedrock geology of Carmen Island consists primarily of dipping Miocene volcanic rocks (Comondú Formation of Hausback, 1984; Sawlan, 1991) overlain by less steeply dipping Pliocene sedimentary rocks and smaller patches of raised Quaternary limestones (Fig. 2; Anderson, 1950). The change from east-dipping Miocene rocks in the northern $2 / 3$ of the island to flatlying and west-dipping rocks in the south is inferred by us (unpubl. field data) to be related to a segment boundary that separates west-dipping normal faults in the north from east-dipping faults in the south. Most of the Pliocene deposits on Carmen Island consist of relatively thin ( $<$ several 100's of meters), gently dipping, impure bioclastic carbonates and calcareous sandstones. By contrast, the Pliocene section exposed at Punta Perico is substantially thicker $(\sim 1100 \mathrm{~m})$, more diverse, and more deformed than other Pliocene sections, and thus preserves the most complete and probably oldest record of Pliocene sedimentation and faulting on the island.

The thick package of Pliocene strata exposed between Bahia Salinas and Punta Perico (Fig. 2B) was originally studied by Anderson (1950), who identified this as the type section for the Carmen Formation. Two other localities on northern Carmen Island were also assigned to the Carmen Formation by Anderson (1950). However, our work has shown that one of those localities was misidentified and exposes only Miocene volcanic rocks, and the other locality contains flat-lying shallow-marine deposits that resemble only a restricted, small exposure of the youngest unit we studied at Punta Perico (upper conglomerate and bioclastic limestone) and therefore does not resemble most of the Carmen Formation exposed at its type locality in the study area (Fig. 2B). The problems encountered with Anderson's (1950) correlation of the Carmen Formation to other parts of the island cause us to regard them as suspect, and we therefore restrict use of the name Carmen Formation to the thick dipping section of Pliocene strata exposed between Bahia Salinas and Punta Perico (Fig. 2B).

\section{Geology of Bahia Salinas to Punta Perico}

The geology of the study area consists of Miocene volcanic rocks and upper Miocene(?) to Pliocene sedimentary rocks that are cut by several large
$\mathrm{N}$-striking and NW-striking normal faults. The geologic map (Fig. 2B) reveals a large area of conglomerate that unconformably overlies Miocene volcanic rocks in the northwest, dips consistently to the southeast, and is bounded on the southwest and northeast by large-offset NW-striking normal faults. In the southeastern part of the area (Fig. 2B), the conglomerate is overlain by a unit of interbedded conglomerate and sandstone, which in turn is overlain by bathyal marlstone and mudstone exposed in smaller exposures along the coast. The SE-dipping section of sedimentary rocks is truncated on the east by a large $\mathrm{N}$-striking normal fault that juxtaposes Pliocene strata in the hangingwall against Miocene volcanic rocks in the footwall (Fig. 2B). The youngest part of the dipping Pliocene section consists of interbedded conglomerate and impure bioclastic carbonates. Younger map units include flat-lying calcarenite and calcarenitic sandstone inferred to be upper Pliocene or Pleistocene in age, and Quaternary alluvium and playa lake deposits.

Excellent exposures in coastal sea cliffs and eroding hills permit direct observation of the thick dipping Pliocene section and two of the major faults in the area (Fig. 3A). The panel in Fig. 3A was produced by tracing over a photograph that was taken looking toward the northeast, along the strike of dipping Sedimentary rocks. The scale in the line drawing was generated by comparing distance measurements on the geologic map (Fig. 2) with the same features in the photograph. Thicknesses of the main stratigraphic units (Fig. 4) were measured directly from this panel; although thicknesses obtained in this way inevitably have some uncertainty (we estimate $\pm \sim 10 \%$ ), they are consistent with the thickness obtained in the eastern measured section (Fig. 8). A geologic cross section (Fig. 3B) was constructed from the photo-overlay panel, revealing the geometry of the large normal fault and related smaller antithetic faults in the eastern part of the map area. The summary stratigraphic section (Fig. 4) also was constructed using information in Fig. 3A.

\section{Stratigraphy and sedimentology}

\subsection{Lower conglomerate}

The lower conglomerate unit covers much of the 
$X$

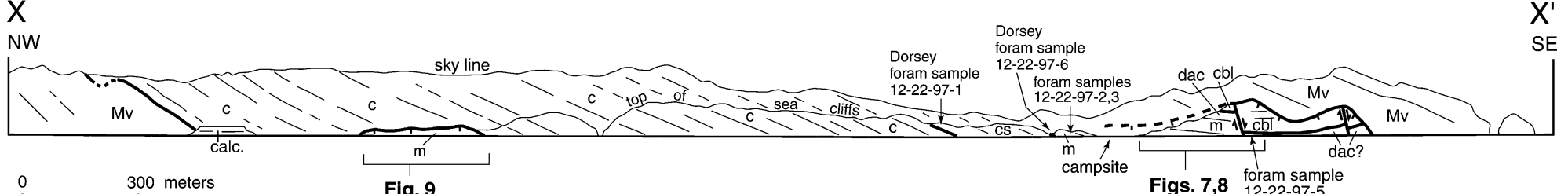

$0 \quad 300$ meters

Fig. 9

Figs. 7,8 foram sample

approx. scale

B

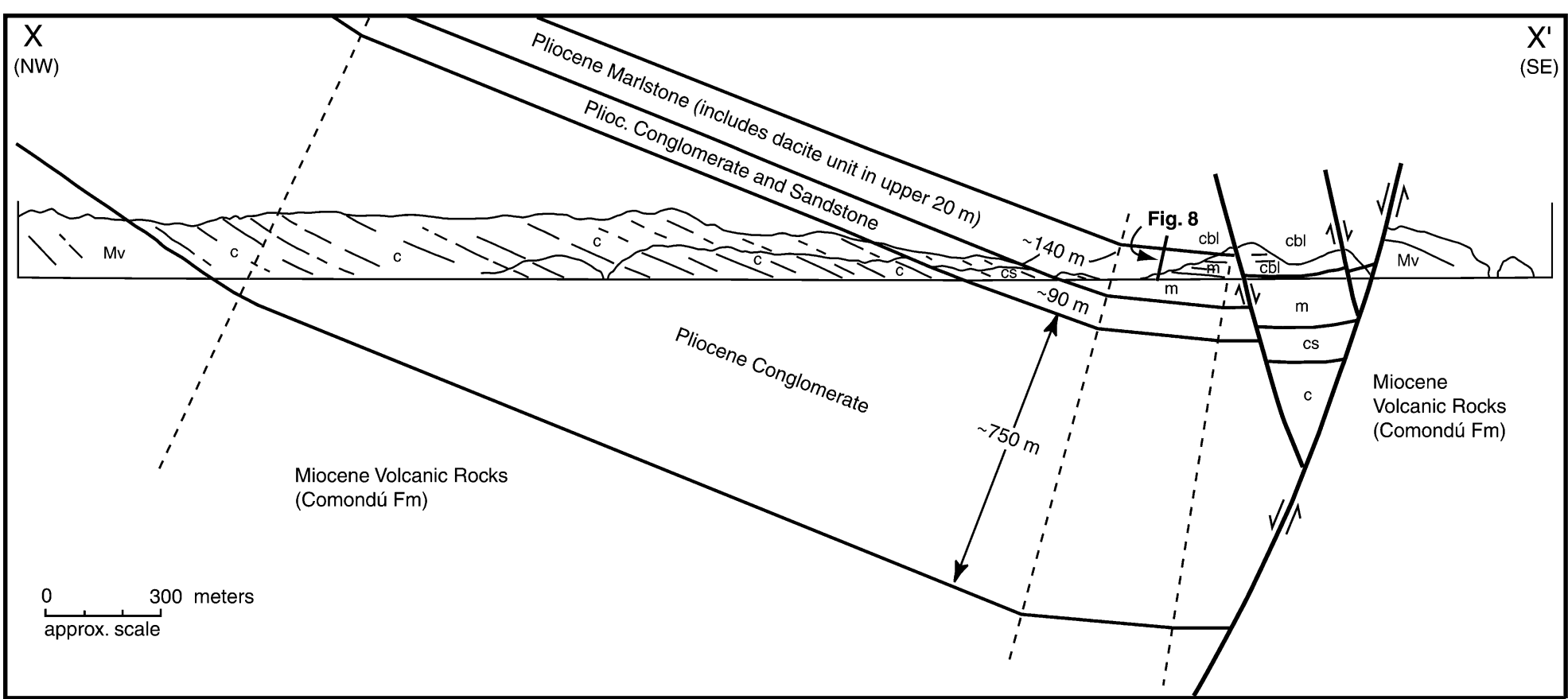

Fig. 3. (A) Line drawing of photograph taken looking NE, showing continuous homocline of SE-dipping Pliocene section and position of Figs. 7-9. Line of section shown in Fig. 2. Thin lines represent bedding surfaces, thick lines represent contacts between units, plain thick lines are depositional contacts, decorated thick lines are normal faults. $\mathrm{C}$ is conglomerate; calc. is Quaternary(?) sandy calcarenite; cbl is conglomerate and bioclastic limestone; dac is dacite unit; $\mathrm{m}$ is marlstone and mudstone; cs is conglomerate and sandstone; Mv is Miocene volcanic rocks (Comondú Formation). (B) NW-SE Geologic cross section of Punta Perico, drafted on top of line drawing in Fig. 3A. 


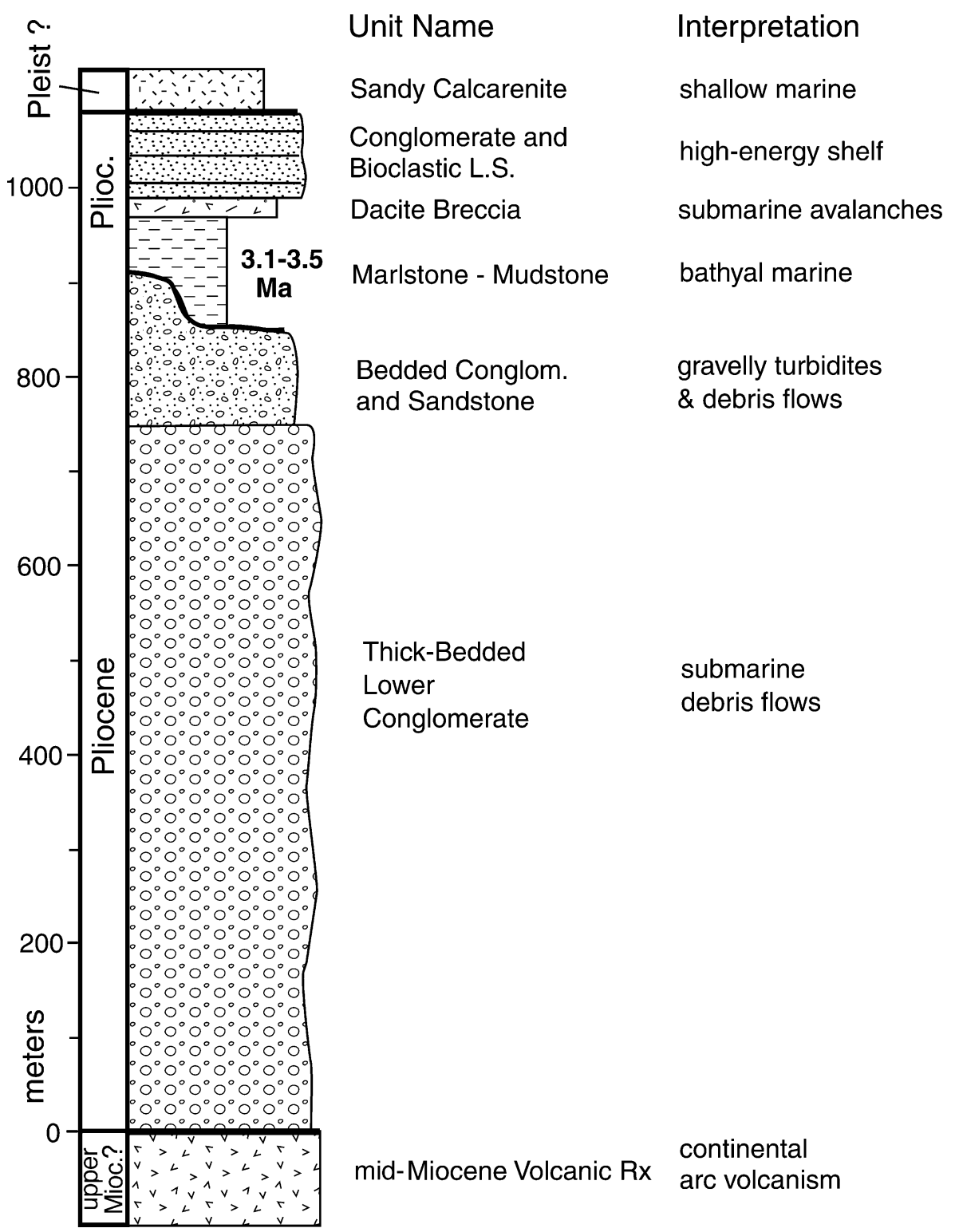

Fig. 4. Summary stratigraphic section of the Punta Perico area, showing interpretation of depositional settings and age of the marlstonemudstone unit (based on biostratigraphy of planktonic foraminifera). Thicknesses determined from cross section in Fig. 3B and measured section in Fig. 8.

map area and makes up a remarkably thick and uninterrupted section, approximately $750 \mathrm{~m}$ thick (Fig. 4). Its basal contact with underlying Miocene volcanic rocks is mappable east of the coastal lagoon (Fig. 2B), but contact relationships are difficult to observe due to talus cover and steep slopes. As viewed from a distance, the Miocene rocks (thick volcanic flows and breccias) are seen to dip approximately $45^{\circ}$ to the SE, about $10^{\circ}$ steeper than the contact with conglomerate and bedding in its lower part $\left(\sim 35^{\circ}\right)$ (Fig. 3A). This indicates the presence of a low-angle unconformity that formed by tilting and erosion of the volcanic rocks, prior to deposition of upper Miocene(?) to Pliocene conglomerate. 
The upper $\sim 450 \mathrm{~m}$ of the lower conglomerate unit, which is $100 \%$ exposed in sea cliffs in the central part of Fig. 3A, contains only conglomerate with no other interbedded lithologies. Below that, the lower $\sim 300 \mathrm{~m}$ is less well exposed in the background hills but the weathering style and our mapping indicate that it also contains only conglomerate down to the base of the section. The conglomerate is poorly to moderately sorted, clast- to matrix supported, and contains pebbles, cobbles and boulders up to $1.5 \mathrm{~m}$ long (long axis) in a pebbly sandstone matrix (Fig. 5A,B). Clasts consist of andesitic to mafic volcanic rocks eroded from the underlying Miocene volcanics. Thin interbeds of sandstone are very rare and discontinuous, and bedding planes are typically defined by concentrations of cobble- to small boulder-size clasts among otherwise homogenous pebble-cobble conglomerate. Moderate internal organization is represented by these larger clast concentrations, which often make up the lower part of weakly developed fining-up depositional units $0.5-2.0 \mathrm{~m}$ thick (Fig. 5B). Clast imbrications are present in some beds, indicating paleo-transport directions that vary from east to southwest. The upper part of this conglomerate unit displays a decrease in bed thickness and increase in degree of organization and thin sandstone interbeds in a $10-15-\mathrm{m}$ transitional interval, indicating a conformable contact with the overlying conglomerate and sandstone unit (Fig. 5A).

The depositional environment of the lower conglomerate unit is difficult to interpret due to the lack of fossils and other lithologies. As noted by previous workers (Winn and Dott, 1979; Hein and Walker, 1982), it can be difficult to distinguish between marine and nonmarine conglomerate in the absence of associated fine-grained facies and paleontological indicators, and it is usually only by association with interbedded shales, sandstones, or fossils that we can confidently determine the depositional setting. In spite of this limitation, the lower conglomerate is interpreted to be a thick succession of marine gravels based on its conformable contact with the overlying conglomerate and sandstone unit, which contains abundant evidence for deposition by turbidity currents in a submarine setting. It is unlikely that alluvial fan conglomerate would be conformably overlain by submarine-slope deposits without any of the intervening environments (fluvial, deltaic, marine shelf) preserved in the stratigraphy. Thus the ungraded, poorly sorted conglomerate beds in this unit are interpreted to record deposition by subaqueous debris flows in a marine slope setting (Hampton, 1972; Hampton et al., 1996; Mulder and Cochonat, 1996). Better organized deposits that include a basal clast concentration overlain by normally graded gravel may record development of limited turbulence and sorting during downslope transformation of gravelly debris flows (Lowe, 1982; Nemec and Steel, 1984; Nemec, 1990).

\subsection{Conglomerate and sandstone}

The thickness of this unit varies from $\sim 90 \mathrm{~m}$ exposed in sea cliffs in the south to more than $160 \mathrm{~m}$ as measured at north beach, where the upper contact is not exposed (Figs. 2-4). It consists of interbedded pebble-cobble conglomerate and sandstone intervals that average $\sim 1-5 \mathrm{~m}$ thick and range up to $\sim 10 \mathrm{~m}$ thick (Fig. 5A). These are well bedded, well organized and sorted deposits that show abundant stratification and normal grading in sandstone and pebbly sandstone, sharp erosive contacts between conglomerate and sandstone beds, broad shallow channel geometries in conglomerate units, and some low-angle cross bedding in channelized conglomerates. Sandstone beds are well sorted, thin-to medium-bedded, and commonly display normal grading from sharp-based coarse-grained pebbly sandstone to fine sand. Vertical burrows $\sim 0.5-1.5 \mathrm{~cm}$ in diameter are present locally. Conglomerate beds are moderately to well sorted, with clasts that range from small pebble to small boulder size, and commonly display clast imbrications with average paleotransport toward the SE. Abundant soft-sediment deformation and liquefaction features and related deformation bands associated with a set of SE-dipping normal faults were observed at the north beach locality (NB, Figs. 2B and 5C,D). Rare coarsening-up intervals consist of thin-bedded sandstone grading upward into bipartite deposits of well bedded sandstone with thin basal pebble and cobble stringers, through thin or medium bedded conglomerate and sandstone, into conglomerate with minor thin sandstone interbeds. The upper contact with the marlstone-mudstone unit is a sharp depositional contact that was not described in detail during 


\section{A}

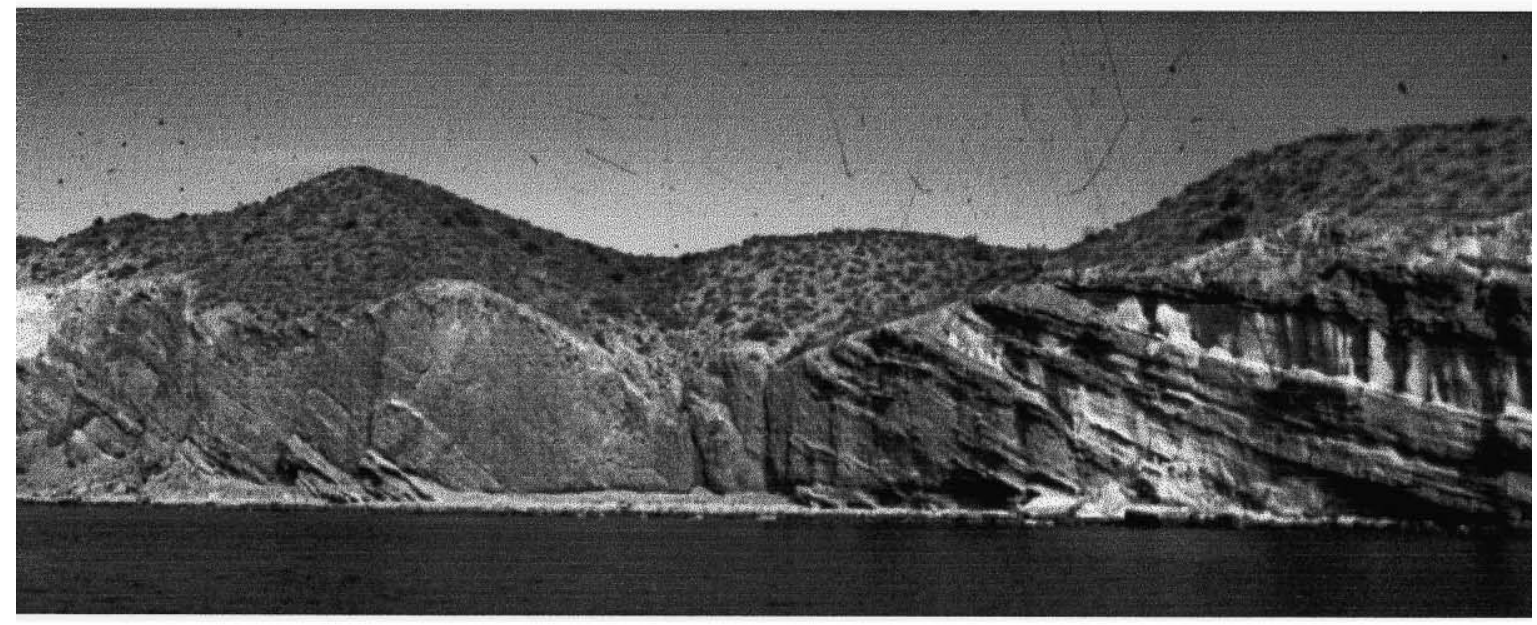

B

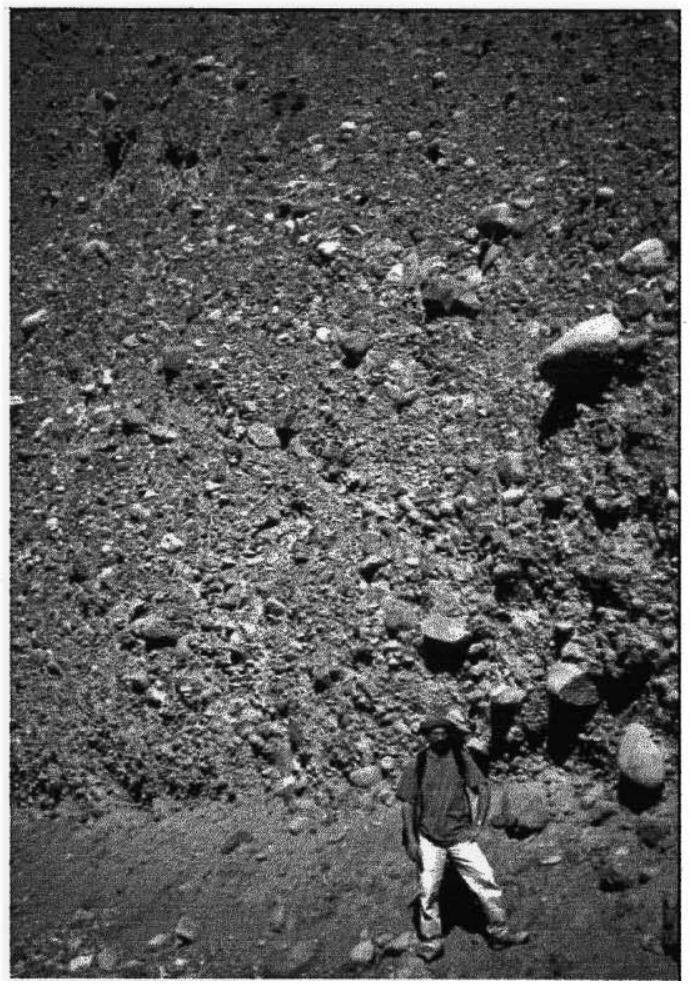

Fig. 5. (A) View looking NE at sea-cliff exposures of the upper part of the lower conglomerate unit (left) overlain along a conformable contact by the conglomerate and sandstone unit. See Fig. 2B for location. (B) Detail of lower conglomerate unit, showing weak bedding defined by concentrations of boulder clasts. (C) Close-up view of a syn-depositional normal fault in conglomerate and sandstone unit at north beach (NB, Fig. 2), view looking SW. Note up-section decrease in fault displacement, clasts dragged into fault zone, sand dikes, and deformation bands above the hammer. (D) Close-up view looking south at soft-sediment faulting at north beach. Note injection of sand dike along central fault plane, and plastic style of offset in lower left. Contact indicated by arrow tips correlates across central fault. 
C

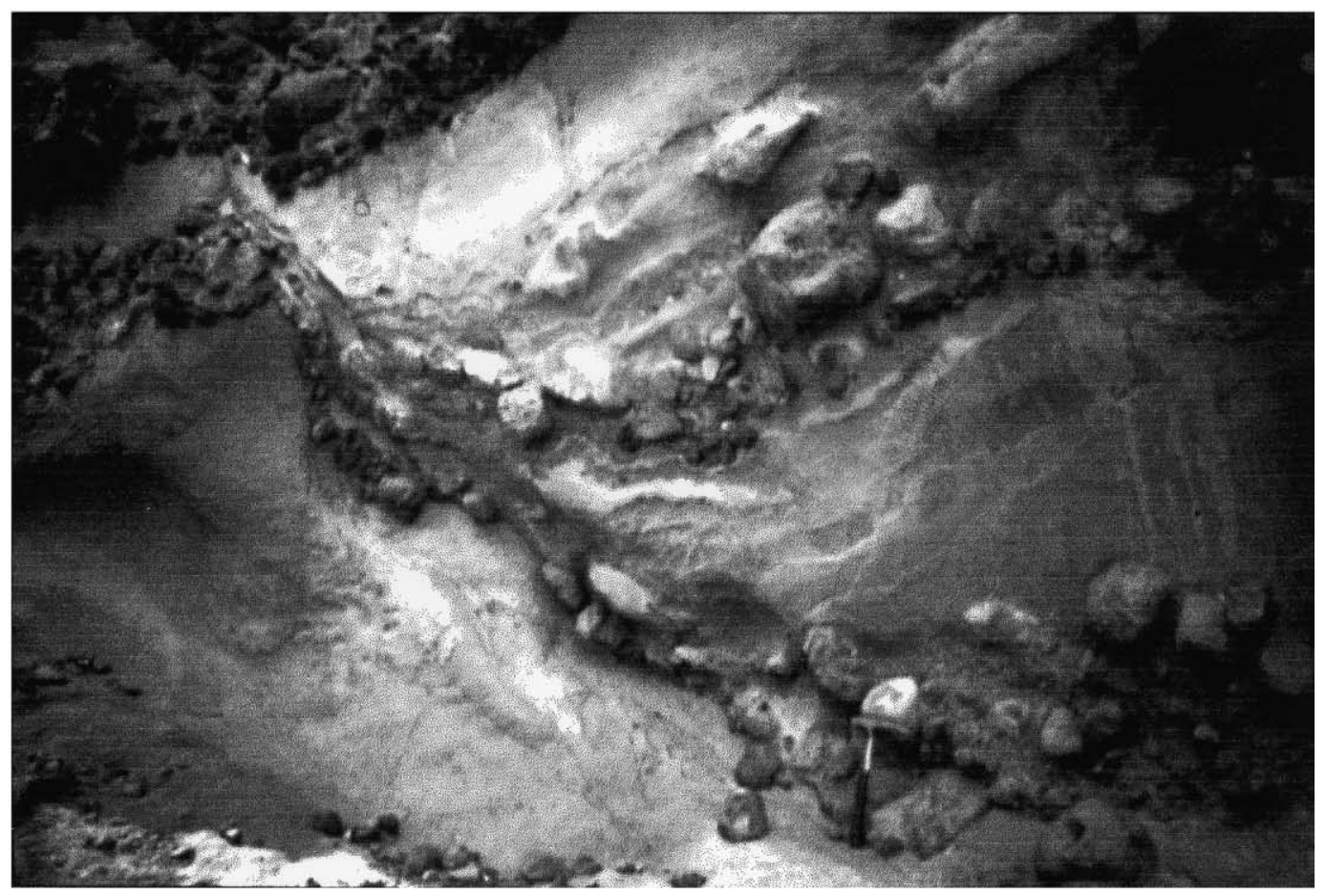

D

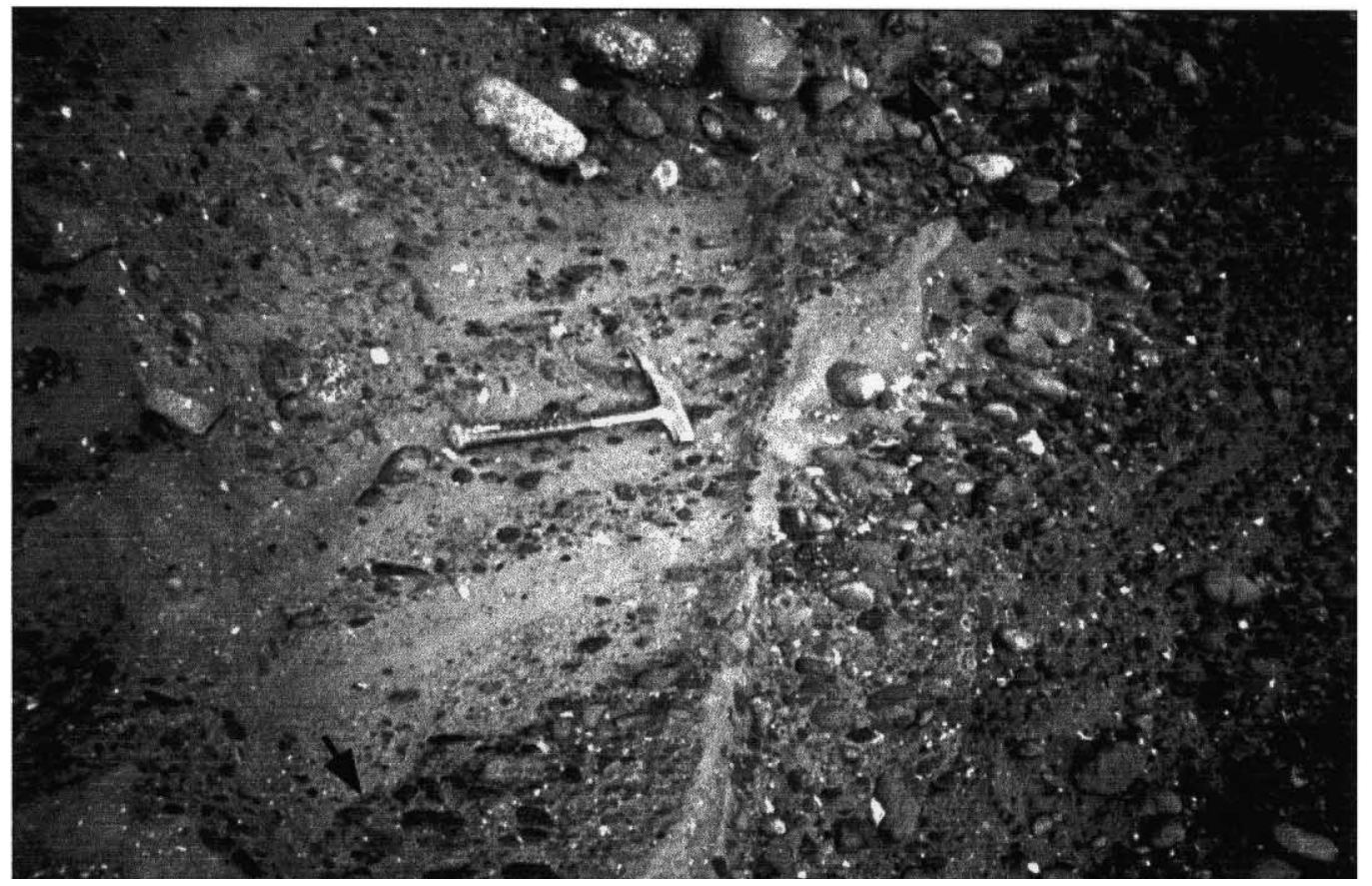


this study. The map pattern (Fig. 2) shows that the contact truncates ESE-dipping strata in the conglomerate and sandstone unit just west of the large, eastern normal fault.

Conglomerate and sandstone in this unit are interpreted to be deposits of gravelly and sandy sediment gravity flows that accumulated in a submarine channel complex, probably at or near the base of a marine slope. We considered a nonmarine origin for this unit, but the facies are notably better sorted than fluvial deposits, lack paleosols, and contain abundant features such as normal grading and distinct gravelsand segregation that are common in marine sandy and gravelly turbidite successions. Thus, sharpbased normally graded sandstone beds are interpreted to be turbidites formed from low-density turbidity currents. Pebble and cobble stringers at the base of some sand beds represent pebbly traction lag deposits that were entrained along the base of sandy turbidity currents. Well sorted and imbricated conglomerate beds are interpreted as the deposits of noncohesive debris flows, or grain flows, that were deposited in close association with the sandy turbidites. This is a classic association of sand and gravel deposition similar to cases described in other studies of marine clastic turbidite and conglomerate successions (Walker, 1975, 1977; Winn and Dott, 1979; Hein and Walker, 1982; Lowe, 1982; Nemec, 1990). Fault-related softsediment deformation and liquefaction features indicate that normal faulting was active during deposition of this unit. The upper contact with marlstone and mudstone is interpreted to be an unconformity based on the truncation of strata implied by the map pattern near the large eastern normal fault (Fig. 2B).

\subsection{Marlstone and mudstone}

This unit is $\sim 120 \mathrm{~m}$ thick and consists of soft, yellow, thin-bedded calcareous marlstone, mudstone, and claystone (Fig. 6A) that contains abundant foraminiferan tests and only minor detrital sand and silt. It commonly displays thin, fine-scale planar laminations defined by subtle variations in grain size and color possibly related to organic content. Normal grading in some beds is defined by the presence of very finegrained, planar laminated detrital sand at the base, with upward decrease in abundance of transported forams in a calcareous mud or clay matrix. Some intervals are massive and structureless due to burrow mixing. Diagenetic features include rare beds that are heavily calcite-cemented and resistant to weathering (Fig. 6A) and fairly common secondary gypsum veins. The upper contact with dacite breccia was not observed directly, but it appears to be conformable based on the presence of foram-rich mudstone interbedded and mixed with breccia and boulder beds. The micropaleontology of this unit is described below.

The marlstone-mudstone unit was deposited by pelagic sedimentation in a quiet marine environment that was mostly isolated from detrital input, in sharp contrast to conditions recorded in the underlying and overlying clastic units. Normal grading in some beds and related sorting of transported foram tests records deposition by very distal, dilute turbidity currents. Abundant fine-scale lamination and very minor bioturbation suggest that the environment was depleted in oxygen during most of its deposition. A bathyal water depth of $\sim 400-500 \mathrm{~m}$ was determined for this unit based on study of benthic forams (see below).

\subsection{Dacite breccia and boulder beds}

The dacite unit is $\sim 20 \mathrm{~m}$ thick and occupies an important stratigraphic transition from bathyal marlstone and mudstone to shallow-marine coarse clastic deposits of the upper conglomerate and bioclastic limestone unit (Figs. 4, 7 and 8). It is divided into two facies: (1) dacite breccia that was observed only in the footwall of the southeastern growth fault and (2) dacite boulder beds observed only in the hangingwall of the same fault (Fig. 7). The breccia facies consists of alternating beds and irregular masses of white breccia and yellow marlstone and mudstone. Breccia beds contain angular fragments of porphyritic dacite (white fine-grained groundmass with phenocrysts of plagioclase, quartz, biotite, and hornblende), $\sim 3-30 \mathrm{~cm}$ in diameter, dispersed in a matrix of yellow mudstone that is intimately mixed with sand- to granule-size dacite fragments (Fig. 6B). The breccia forms chaotically deformed beds and irregular masses $\sim 1-3 \mathrm{~m}$ thick that are interlayered with and truncate thin-bedded marlstone and mudstone, revealing abundant features 
of soft-sediment deformation, liquefaction, and chaotic mechanical mixing.

Dacite boulder beds are massive and ungraded, $\sim 0.5-2 \mathrm{~m}$ thick, and contain subangular to subrounded, cobble- to boulder-size clasts encased in a matrix of white laminated dacitic sand that contains small pockets $(2-10 \mathrm{~cm}$ thick) of dacitebearing volcaniclastic pebble conglomerate (Fig. 6C). Some beds consist of single-clast horizons of dacite boulders up to 1-2 $\mathrm{m}$ in diameter, with laminated dacite sand draped around the edges of isolated clasts. The boulder beds are interbedded with foram-bearing mudstone and heterolithic volcaniclastic conglomerate and sandstone, and most contacts with interbedded lithologies are sharp. A detailed section was not measured through this unit in the hangingwall of the growth fault (Fig. 7), but our observations indicate that lithologies interbedded in the lower part of the unit consist of bathyal marlstone and mudstone, and that stratified sandstone and conglomerate are interbedded in the upper part. The upper contact with conglomerate and bioclastic limestone is sharp and appears erosional. Laser-beam ${ }^{40} \mathrm{Ar}-{ }^{39} \mathrm{Ar}$ dating of individual biotite crystals in dacite collected from a boulder bed yielded consistent ages of $\sim 12 \mathrm{Ma}$ (P. Renne, personal comm., 1999).

The dacitic deposits are interpreted to be a complex accumulation of submarine landslides, rock falls, and debris flows that were shed from unstable exposures of Miocene volcanic rocks on either submarine or subaerial steep slopes (e.g. Nemec, 1990). Although textures in the breccia facies resemble pepperites that form by syn-eruptive intrusion of magmas into shallow wet sediments, the Miocene age of a dacite boulder requires that the dacite is not Pliocene, and instead was derived from older bedrock exposures by slope failures. Thus we conclude that breccia facies record intense fracturing of large masses of dacite that slid catastrophically into the basin and were mechanically mixed with marl deposits during rapid emplacement and deformation on the sea floor. Boulder beds represent submarine avalanches and/or debris flows that were generated by mass wasting events on a steep submarine slope. Processes of avalanching are favored for the boulder beds because they generally lack a syndepositional matrix. Matrix in these beds consists of well laminated dacitic sand that drapes over and around individual clasts (Fig. 6C) and probably was deposited by turbidity currents that trailed behind the bouldery avalanches, depositing their suspended sand load after deposition of isolated clasts. The slight rounding observed in boulder clasts could also be produced by this process. Stratified volcaniclastic conglomerate and sandstone interbedded in the upper part of the boulder beds unit have an uncertain origin. They may be deposits of gravelly grain flows and turbidity currents produced on a steep slope, or they could be coarse-grained deposits of a high-energy shallow marine setting, as is inferred for the overlying unit. The latter interpretation would imply a very rapid phase of uplift during this time interval. If the first interpretation is correct, then the transition to shallow-marine conditions is represented by the sharp contact with overlying conglomerate and bioclastic limestone, which also would imply a short-lived rapid uplift event.

\subsection{Upper conglomerate and bioclastic limestone}

This unit is at least $\sim 80 \mathrm{~m}$ thick (upper contact not exposed) and is exposed only in the southeast part of the study area where it is faulted against Miocene volcanic rocks (Figs. 2 and 3). It makes up alternating units of: (1) well stratified sandy pebble-cobble conglomerate with thin interbeds of bioclastic limestone and variable amounts of broken shell debris in the matrix and (2) well stratified sandy to pebbly bioclastic limestone (calcarenite and shell hash) commonly with thin sandstone and conglomerate interbeds (Figs. 6D, 7 and 8). Stratification is pervasive and consists primarily of planar bedding with some low-angle cross bedding and rare shallow channel geometries. Carbonate debris consists of broken fragments of calcareous molluscan faunas including pectens, oysters, corals, barnacles and rhodoliths (concentrically layered calcareous red algae). We observe a wide range of mixing of coarse siliciclastic detritus and fragmental bioclastic carbonate, varying from very pure concentrations to mixtures in which the two components are sub-equal. Most bedding contacts are sharp and erosional, with planar to broadly lenticular geometries.

The conglomerate and bioclastic limestone unit formed in a high-energy marine-shelf setting in which strong traction currents modified and reworked a substrate of coarse-grained, mixed 


\section{A}

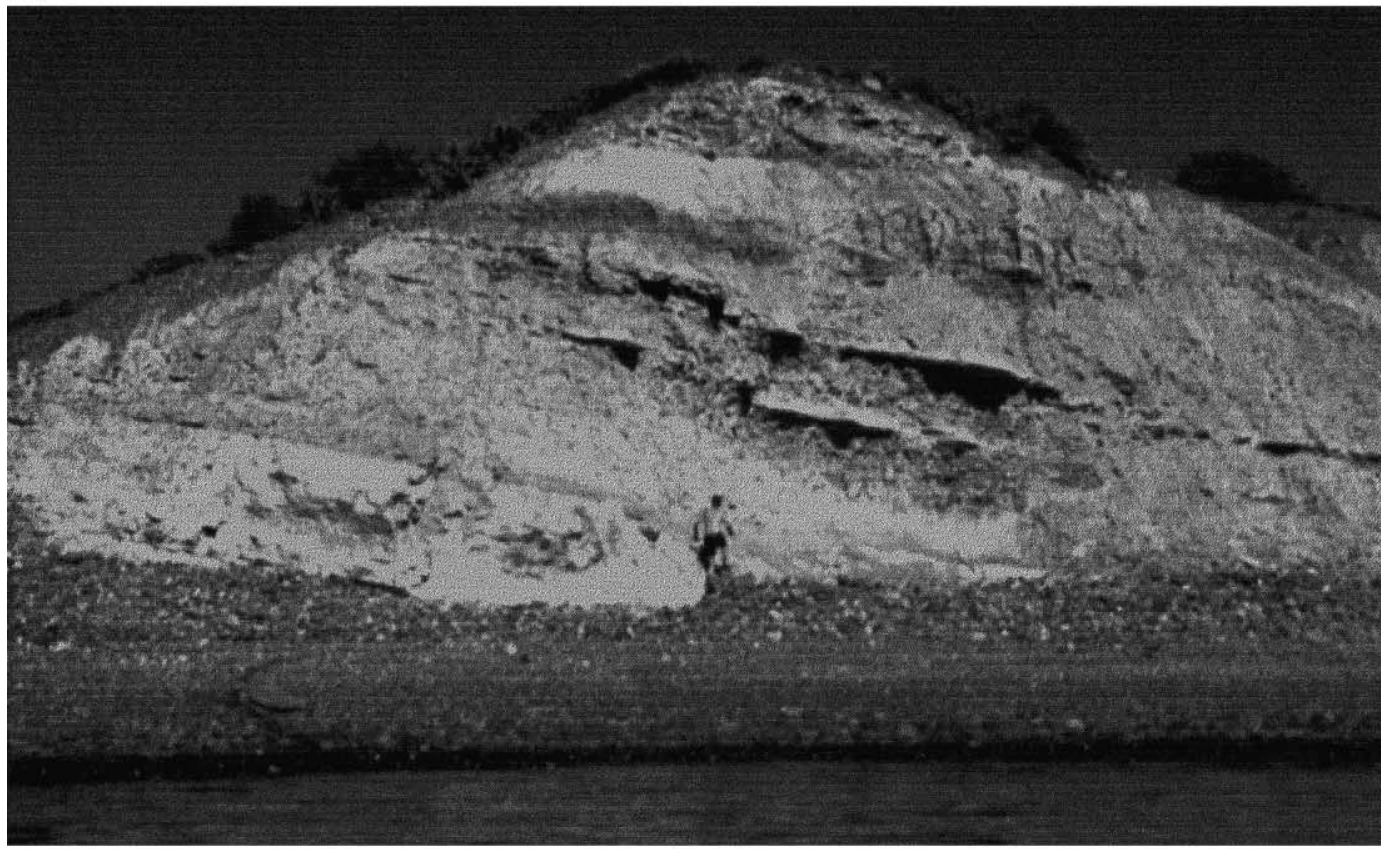

B

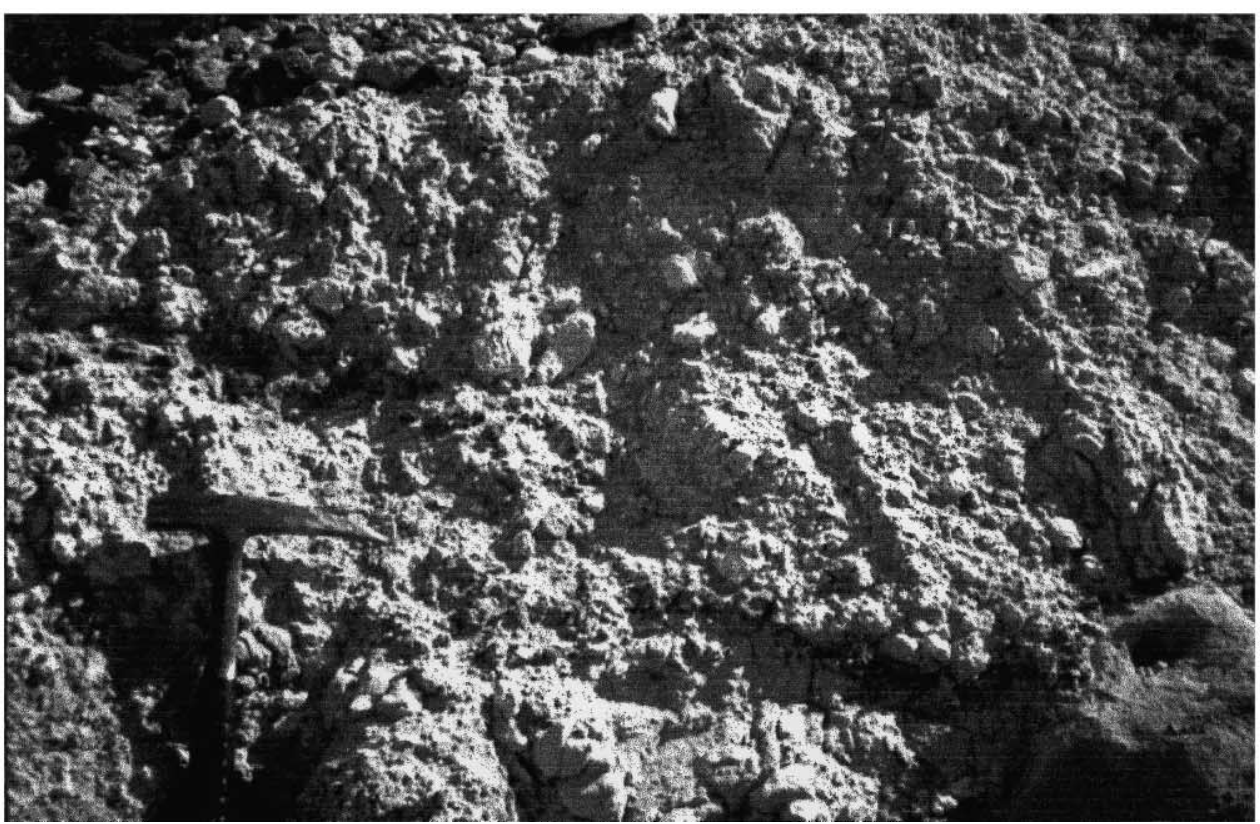

Fig. 6. (A) Typical outcrop of yellow marlstone and mudstone. (B) Close-up view of dacitic breccia. (C) Example of a dacite boulder bed, showing laminated dacitic sand draped onto and around isolated boulder clasts. (D) Well stratified, interbedded conglomerate and bioclastic limestone in the hangingwall of the growth fault shown in Fig. 7. 


\section{C}

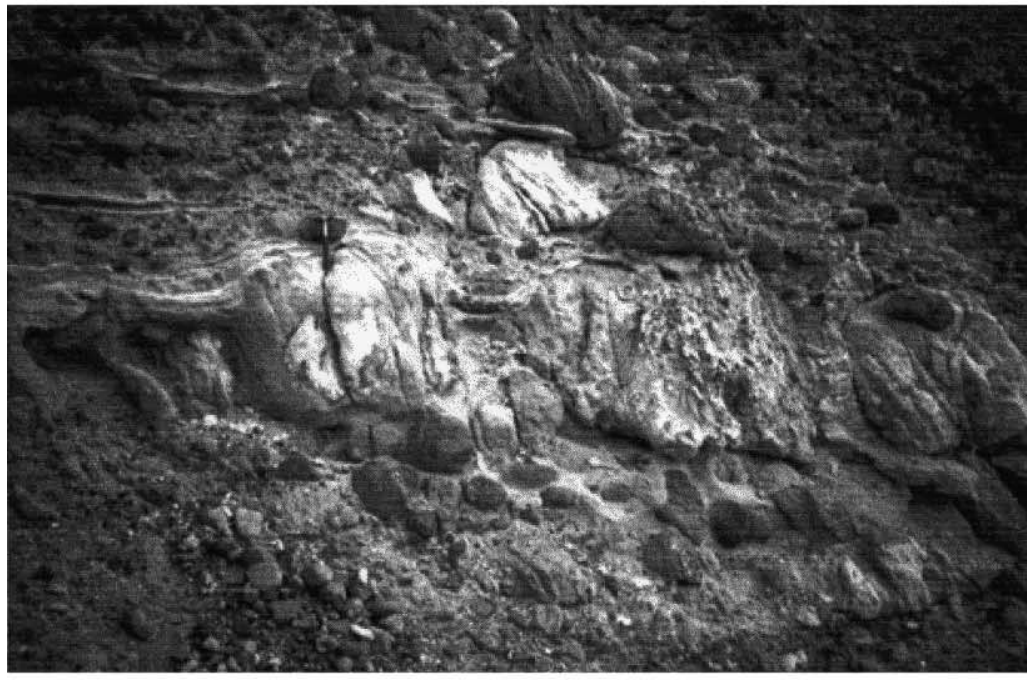

D

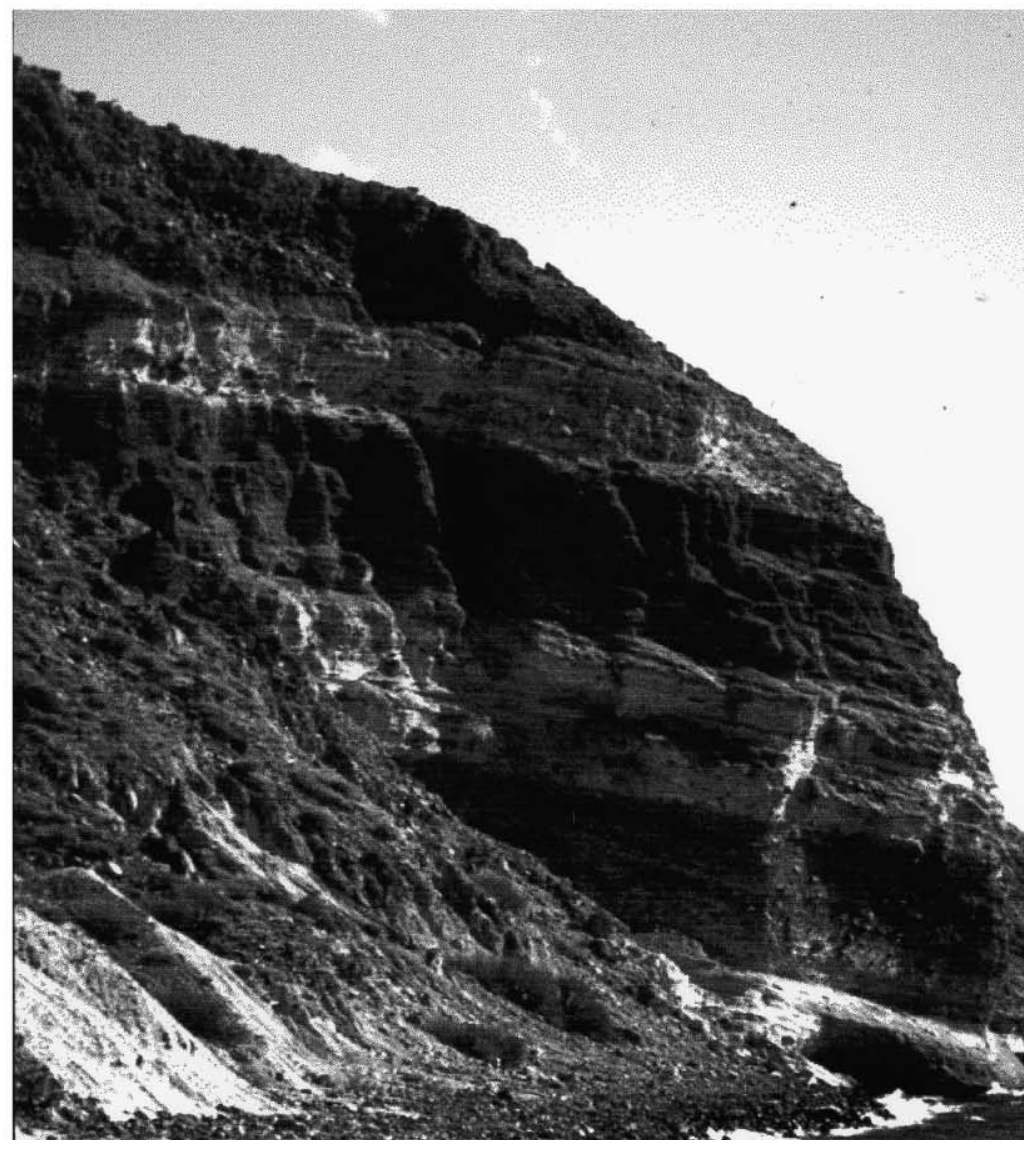



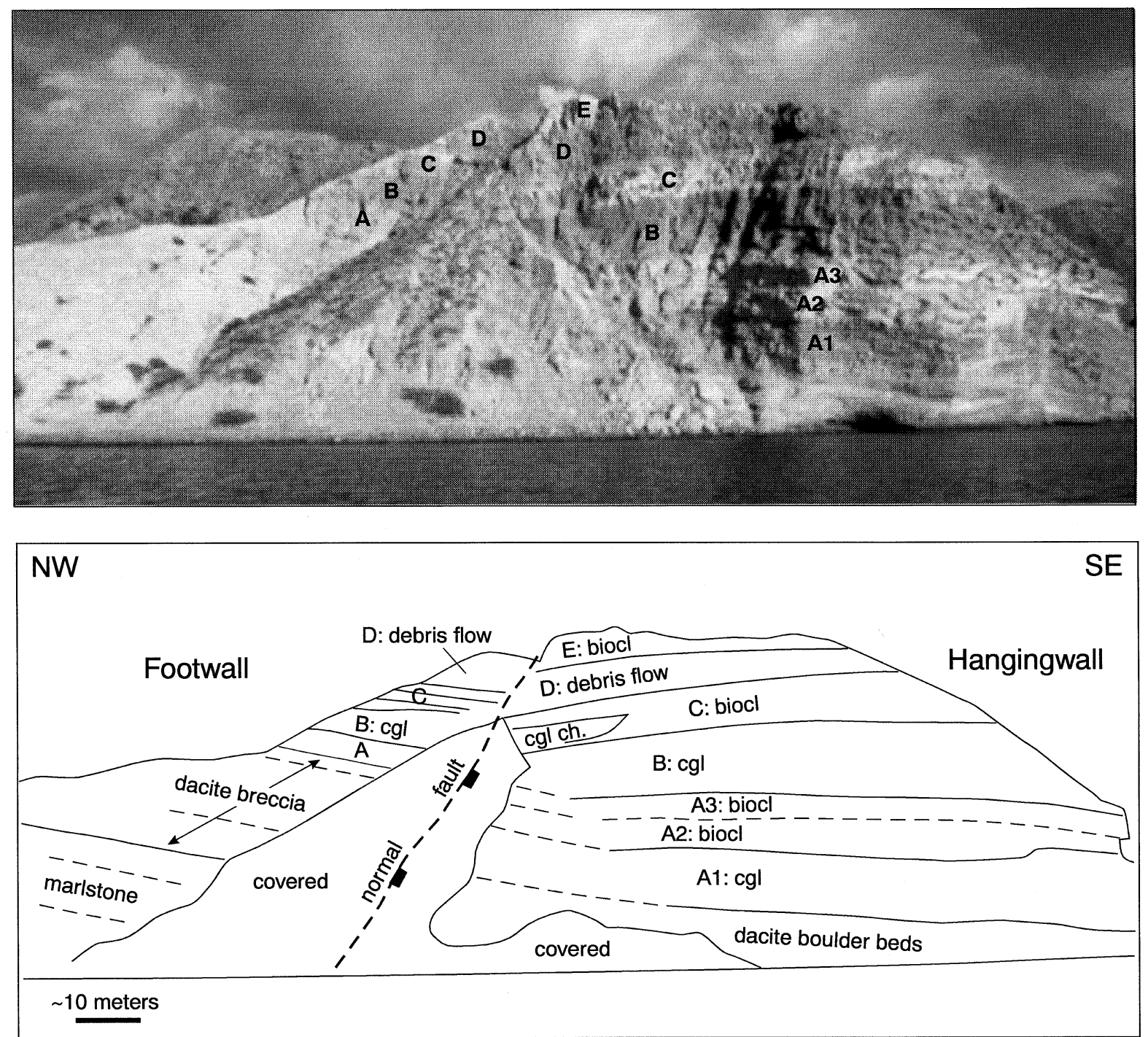

Fig. 7. Photograph (top) and line drawing (bottom) of southeast-dipping antithetic growth fault in southeast part of study area. Apparent dip to northwest is due to oblique view in the photograph; actual dip is steeply to the southeast, obliquely toward observer. Correlation of units across fault was determined from field notes, measured section (Fig. 8), and detailed photo-analysis. Note pronounced thickening of unit A, and to lesser degree units B and C, from the footwall to the hangingwall. See Figs. 2B and 3A for location.

carbonate and siliciclastic detritus. The carbonate debris was derived from nearby lower-energy settings where molluscan and coral faunas lived, although the uncommon rhodoliths may have grown and lived within this setting. The pervasive abundance of planar to low-angle cross stratification, sharp bedding contacts, abundance of coarse bioclastic detritus, and rare channel forms, all suggest that deposition took place above fairweather wave base within the shoreface. Alternatively, it is possible that high-energy reworking of the deposits took place by strong tidal rip currents in somewhat deeper water. Accumulation of more than $\sim 80 \mathrm{~m}$ of section in a shallow marine setting 
letters indicate stratigraphic units shown in Fig. 7

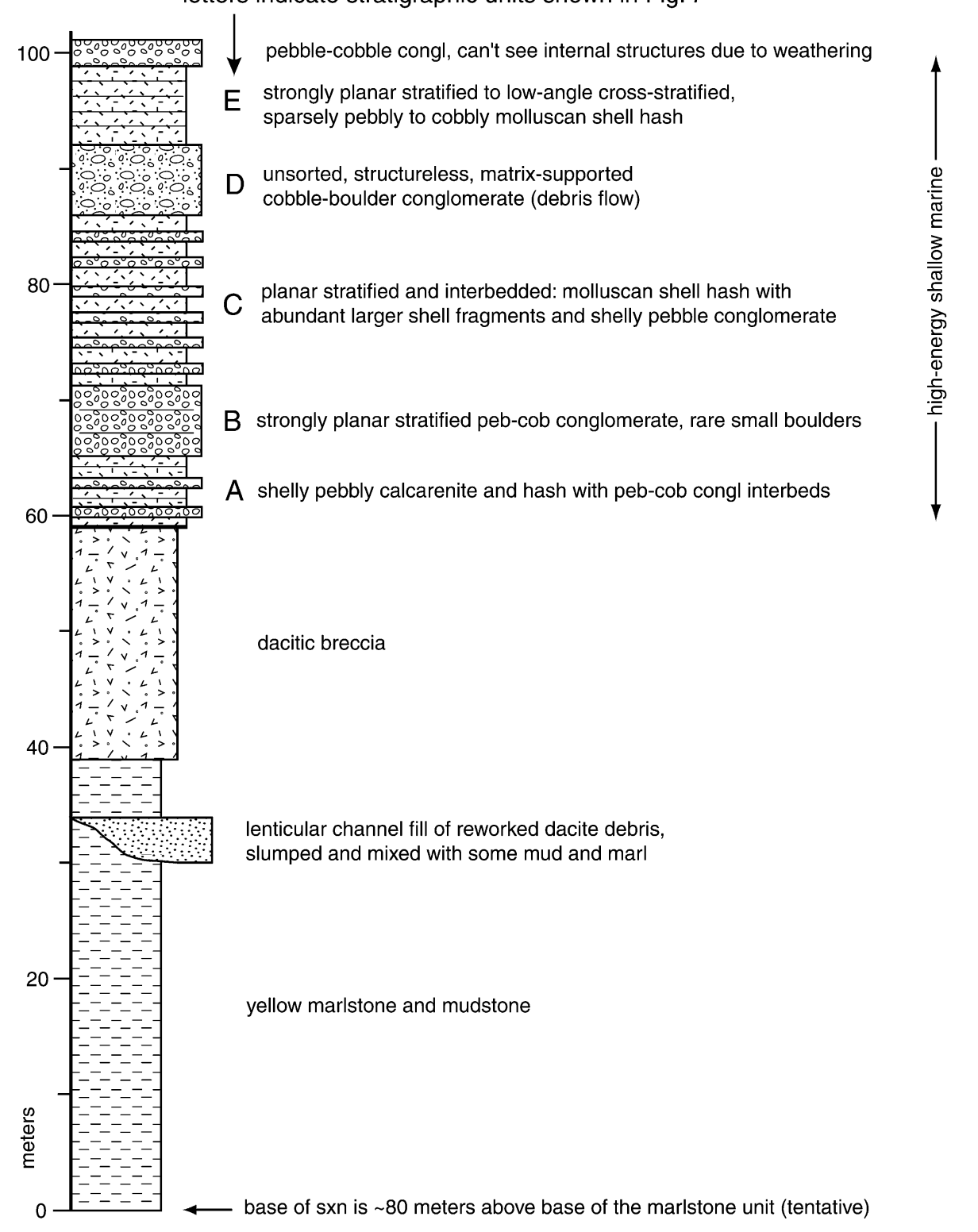

Fig. 8. Measured section of the upper part of the Pliocene section, footwall of the antithetic growth fault seen in Fig. 7. See also Figs. 2B and 3 for location.

would require that basin subsidence during this interval was about equal to sediment accumulation rate. Although these deposits bear some similarities to mixed carbonate and siliciclastic sediment gravity flow deposits recently documented in the Loreto basin (Dorsey and Kidwell, 1999), the lack of inverse to normal grading in conglomerate beds, lack of normal grading and other turbiditic features in the carbonate beds, and lack of largescale clinoform cross bedding, all indicate that this unit was not deposited by debris flows and turbidity currents in foresets of Gilbert-type deltas. These deposits do, however, closely resemble other examples of mixed bioclastic carbonate and 
siliciclastic sediments in the Loreto basin (sequence 3), where they have been interpreted as traction deposits of a high-energy, carbonateproducing shallow shelf setting (Dorsey et al., 1997; Dorsey and Umhoefer, 2000).

\section{Paleobathymetry}

Quantitative analysis of benthic foraminifera in this study provides a means of: (1) estimating the water depth (paleobathymetry) in which the sediments were deposited, (2) assessing the benthic environmental settings in which deposition took place and (3) establishing the magnitude of downslope transport of sediments by noting the sources and abundance of redeposited species. Samples analyzed for this report were collected exclusively from the marlstone-mudstone unit of the Carmen Formation exposed in sea cliffs NW of Punta Perico (Fig. 2B). Substantial thicknesses of conglomerate within the section both stratigraphically above and below the marlstone unit were not sampled or, where sampled, did not yield well preserved microfossils. Despite the limited sample base, the foraminiferal assemblages recovered from the marlstone unit are generally well preserved, abundant, and provide clear evidence of the paleoenvironmental, paleobathymetric, and paleoceanographic history of this area.

\subsection{Methods}

Twenty-one samples from the marlstone unit were analyzed for benthic foraminifera. Samples were treated with kerosene and water and washed over a 200 mesh screen; 17 samples yielded good to excellent assemblages. An average of 315 specimens were identified and counted in 14 samples with three samples yielding less than 60 specimens each. Relative abundances of species were tabulated in terms of percent of the total population counted in a given sample. Identification and paleoenvironmental and paleobathymetric interpretation of the foraminifera were aided by the fact that many of the species found in these sediments are still living in the modern Gulf of California. In addition, those benthic species which are thought to be extinct are close relatives of living taxa and display biofacies associations essentially identical to their modern counterparts. Indeed, foraminifera from the Carmen Formation were first described by Natland (1950) who emphasized their similarity to Recent, Pleistocene, and Pliocene faunas described from elsewhere along the Pacific coasts of Mexico and Central America.

Recurrent distributional patterns of Holocene littoral, neritic, and bathyal benthic foraminifera in the subtropical-tropical eastern Pacific Ocean form the basic model used to interpret fossil foraminifera in this study. Key reports describing these associations and patterns include Bandy and Arnal (1957); Smith (1963, 1964); Lankford and Phleger (1973); Streeter (1972); Golik and Phleger (1977); Ingle and Keller (1980), and Resig (1981). Special emphasis was placed on comparison with modern foraminiferal distributions in the Gulf of California as described by Bandy (1961); Brenner (1962); Phleger (1964), andDouglas et al. (1998b). In particular, Douglas et al. (1998b) have demonstrated the dynamic nature of water mass-sediment-benthic foraminiferal relationships in modern shelf and slope environments in the Gulf of California, including biofacies represented in marl deposits of the Carmen Formation.

Comparison of modern biofacies compositions allowed common species to be assigned to a series of biofacies representing littoral to middle bathyal depth settings of the shelf and slope (Table 1). Extinct species were assigned to a given biofacies following Ingle (1980) and their reported associations with still living taxa of known environmental and bathymetric preferences. In constructing biofacies, reference was also made to other reports in which benthic foraminiferal were used to interpret the paleobathymetric and paleoenvironmental history of Neogene sequences in the Gulf of California and adjacent areas (Ingle, 1974; Boehm, 1984; McCloy et al., 1988; McDougall 1985; Carreño, 1992; Douglas et al., 1998a; and McDougall et al., 1999). Not all species identified in samples were assigned to a given biofacies resulting in biofacies composed largely of common to abundant species and those with the least equivocal environmental signatures.

\subsection{Paleobathymetric and paleoenvironmental trends}

Variation in the relative abundances of benthic foraminiferal biofacies and selected species through the lower $\sim 30 \mathrm{~m}$ of the marlstone unit demonstrates 
Table 1

Benthic formaminiferal biofacies of the Pliocene Carmen Formation, Carmen Island, Gulf of California, Mexico ${ }^{\mathrm{a}, \mathrm{b}}$

\section{Littoral-inner neritic ${ }^{\mathrm{c}}$ biofacies $(\mathbf{0 - 5 0} \mathrm{m})$}

Amphistegina gibbosa d'Orbigny ${ }^{* * *}$

Bolivina tongi filicostata Cushman \& McCulloch

Buliminella elegantissima (d'Orbigny)

Cancris auriculus (Fitchell \& Moll)

Cibicides fletcheri Galloway \& Wissler

Cicibides lobatulus (Montagu) ${ }^{*}$

Cribrononion lene (Cushman \& McCulloch)

Cymbaloporetta milletti Cushman \& Valentine

Dyocibicides biserialis Cushman \& Valentine

Elphidium spp.

Gavelinopsis companulata (Galloway \& Wissler) ${ }^{* *}$

Gypsina vesicularis Parker \& Jones

Hanzawaia nitidula (Bandy)*

Massilina spp.

Nodobaculariella cassis (d'Orbigny)

Nonionella spp.

Planispirinella exigua Brady

Planorbulina acervalis Brady

Quinqueloculina spp. ${ }^{* *}$

Reusella aquea Cushman \& McCulloch

Textularia schencki Cushman \& Valentine

Triloculina inornata d'Orbigny*

Outer neritic-shelf edge biofacies (50-150 m)

Angulogerina angulosa (Williamson)

Angulogerina agrestis Todd

Angulogerina baggi (Galloway \& Wissler)

Angulogerina hughesi (Galloway \& Wissler)

Angulogerina occidentalis (Cushman)

Bolivina acutula Bandy

Bolivina acuminata Natland*

Bulimina denudata Cushman \& Parker

Buliminella curta Cushman \& Parker

Cancris (Valvulineria) inflatus (d'Orbigny) ${ }^{* * *}$

Cassidulina minuta Cushman

Cibicides mckannai Galloway \& Wissler

Epistominella bradyana s.1. (Cushman) ${ }^{* * *}$

Hanzawaia panamensis Natland**

Planulina ariminensis d'Orbigny

Planulina ornata d'Orbigny

Upper bathyal biofacies (150-500 m)

Angulogerina carinata Cushman ${ }^{* *}$

Bolivina humilus Cushman \& McCulloch ${ }^{* * *}$

Bolivina interjuncta s.l. Galloway \& Wissler ${ }^{* * \mathrm{~d}}$

Bolivina pacifica Cushman \& McCulloch ${ }^{\mathrm{d}}$

Bolivina plicata d'Orbigny

Bolivina (Loxostomum) pseudoberichi Cushman

Bolivina seminuda s.s. Cushman ${ }^{\mathrm{d}}$

Buliminella tenuata s.1. Cushman ${ }^{* * \mathrm{~d}}$

Cancris carmenesis Natland*

Cassidulina corbyi Cushman \& Hughes

Cassidulina quadrata Cushman \& Hughes
Table 1 (continued)

Cassidulina subcalifornia Drooger*

Fursenkoina bramletti (Galloway \& Morrey)

Fursenkoina complanata (Egger)

Globobulimina pacifica Cushman ${ }^{\mathrm{d}}$

Globobulimina affinis (d'Orbigny)

Gyroidina multilocula Coryell \& Mossman*

Gyroidina (?) rothwelli Natland

Gyroidina carmenensis Natland

Gyroidina nitidula (Schwager)

Suggrunda eckisi Natland*d

Uvigerina excellens Todd $^{* * * *}$

Uvigerina peregrina s.1. Cushman ${ }^{\mathrm{d}}$

Upper middle bathyal biofacies (500-1000 m)

Bolivina argentea Cushman

Bolivina sinuata s.l. Galloway \& Wissler ${ }^{* * *}$

Bolivina spissa Cushman

Bolivina subadvena s.l. Cushman ${ }^{* * *}$

Bulimina pagoda Cushman

Cassidulina delicata Cushman ${ }^{* * * *}$

Cassidulina tumida Natland*

Cassidulinella pliocenica Natland ${ }^{* *}$

Chilostomella ovoidea Reuss $^{\mathrm{d}}$

Cibicides spiralis Natland

Galliherina (Bulimina) uvigerinaformis (Cushman \& Kleinpell)

Pullenia aff. riveroi Bermudez

Uvigerina peregrina dirupta Todd

Valvulineria araucana (d'Orbigny)

Valvulineria oblonga (d'Orbigny)

${ }^{a}$ Highest relative abundances recorded for dominant species (in terms of percent of total benthic population in a given sample) are marked as follows: ${ }^{*}=5-10 \%,{ }^{* *}=10-25 \%$, and ${ }^{* * *}=25 \%$ or higher.

${ }^{\mathrm{b}}$ Note that not all species identified in Carmen Formation samples were included in the biofacies listed in this table and not all species assigned to a given biofacies are present in every assemblage assigned to this biofacies.

c The term neritic is equivalent to the term shelf of some authors.

d Species commonly associated with the impingement of the oxygen minimum zone in the modern Gulf of California and off Central America.

that these sediments were deposited at a water depth of approximately 400-500 m (Fig. 9B). Thus, the estimated water depth is similar to that originally proposed for the Carmen Formation by Natland (1950) in his pioneering study of foraminifera from these deposits. Relatively high abundances of upper bathyal species including Bolivina interjuncta, $B$. humilus, Buliminella tenuata and Uvigerina excellens are present throughout the section analyzed. Specifically, high abundances of Bolivina humilus and other 
bolivinids match biofacies associated with the impingement of the oxygen minimum layer in the modern Gulf of California and off Central America. The combined association of a Cancris dominated shelf edge biofacies together with the Bolivina-rich upper bathyal biofacies in the upper part of the section may indicate somewhat shallower depths ca. 350$400 \mathrm{~m}$ based on observations by Douglas et al. (1998a,b). However, there is much evidence of sediment redeposition in this section as noted below, which is probably responsible for the anomalously high abundance of outer neritic-shelf edge taxa near the middle part of the analyzed interval (Fig. 9B). In addition, significant abundances of upper middle bathyal species including Bolivina subadvena and Cassidulina delicata support deposition in the lower range of upper bathyal water depths. Higher abundances of upper middle bathyal taxa dominate assemblages in the lower half of the short section analyzed and suggest that the water depth approached or exceeded $500 \mathrm{~m}$ during deposition of this material.

Biofacies patterns indicate that vigorous downslope movement of sediments characterized this period in the basin history, consistent with sedimentological evidence of turbidites and sediment gravity flows in the underlying conglomerate and sandstone unit. Sources of displaced material include littoral, inner neritic and shelf edge environments as clearly marked by spikes in the relative abundances of species indicative of these settings (Fig. 9B). For example, high abundances of the shelf edge species Cancris inflatus occur in the middle of the section along with high abundances of both upper and middle bathyal taxa. However, the most dramatic evidence of this process is seen in the lower part of the studied interval where assemblages composed exclusively of littoral and inner neritic species occur within thin sandy marlstone turbidite beds. Occurrences of Amphistegina gibbosa, a tropical reef dwelling species no longer living in the eastern Pacific Ocean (Crouch and Poag, 1979), highlight redeposited littoral sediments throughout the section. Unfortunately, samples collected within the thick conglomerates underlying the marlstone unit did not yield identifiable foraminifera. However, a sample collected from mudstone interbedded with dacite boulder beds that immediately overly the marlstone unit (foram sample 12-22-97-5 in Figs. 3A,B and 7) yielded a foraminiferal assemblage dominated by upper bathyal taxa indicating this unit also was deposited in a water depth of ca. 400-500 m. Finally, a sample of sandy coquina lying directly on top of the conglomerate and sandstone unit at the basal contact of the marlstone (foram sample 12-22-97-6 in Fig. 3A) contains a complete mixture of littoral through upper middle bathyal species representing the cumulative result of redeposition of littoral and neritic species within an upper bathyal setting. Downslope redeposition of benthic foraminifera is common on the relatively steep basin margins of the modern Gulf of California (Bandy, 1961) and this process was clearly active during deposition of the marlstone unit.

\section{Biostratigraphy and age}

Exposures of the Carmen Formation on Carmen Island were originally mapped by Anderson (1950) with fossil mollusks in these sediments described by Durham (1950) and foraminifera described byNatland (1950). Durham assigned a middle Pliocene age to the Carmen Formation based largely on correlations with molluscan faunas described from the Pacific coasts of Central and South America. Natland concluded that the foraminiferal assemblages were upper Pliocene in age based on his correlations with microfaunas reported from the Charco Azul Formation in Panama and the relatively well studied Neogene benthic foraminiferal biostratigraphy established in the Los Angeles and Ventura basins of California. As it turns out, these early workers were essentially correct in their assignment of middle and upper Pliocene ages

Fig. 9. (A) Line drawing of coastal exposure of marlstone unit, about $3 \mathrm{~km}$ northwest of Punta Perico. Numbers beneath dots indicate J. Ingle foram samples (numbered 3-26-88-1, -2, etc.). See Fig. 2B for location. (B) Estimated age, planktonic foraminiferal and calcareous nanoplankton zones, stratigraphic variation of benthic foraminiferal biofacies and selected benthic foraminifera, and paleobathymetry for the lower $30 \mathrm{~m}$ of the marlstone unit. Note upermost meter of conglomerate and sandstone unit at base of the section. See Table 1 for composition and bathymetric ranges of benthic foraminiferal biofacies, and text for biostratigraphic evidence for zonal assignments. Correlation of planktonic zones with radiometric time scale follows Berggren et al. (1995). 

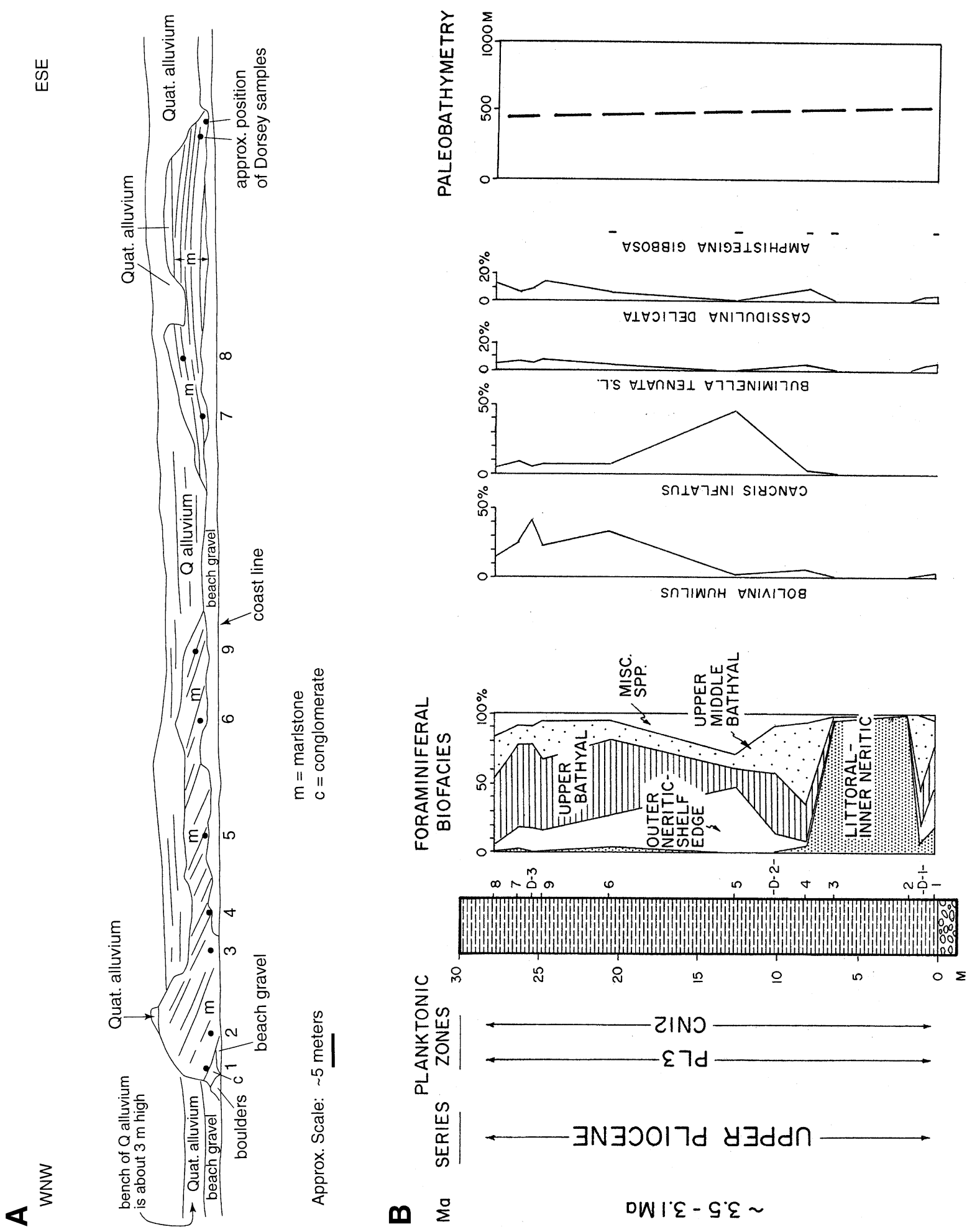

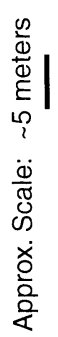
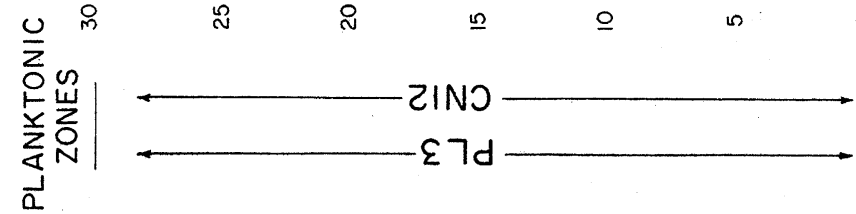$$
\text { 繁 }
$$

m $\Sigma^{\circ}$

DWIE - GंE 
Table 2

Planktonic foraminifera and calcareous nannoplankton identified in the marlstone unit of the Pliocene Carmen Formation, Punta Perico section $^{\mathrm{a}}$

\author{
Planktonic Foraminifera \\ Globigerina apertura Cushman \\ Globigerina bulloides d'Orbigny \\ Globigerina decoraperta Takayanagi \& Saito \\ Globigerina falconensis Blow \\ Globigerina quinqueloba Natland \\ Globigerina rubescens Hofker \\ Globigerina woodi Jenkins \\ Globigerinita glutinata (Egger) \\ Globigerinita uvula (Ehrenberg) \\ Globigerinoides bolli Blow \\ Globigerinoides conglobatus (Brady) \\ Globigerinoides extremus Bolli \\ Globigerinoides immaturus Leroy \\ Globigerinoides obliquus Bolli \\ Globigerinoides quadrilobatus (d'Orbigny) \\ Globigerinoides ruber (d'Orbigny) \\ Globigerinoides sacculifer (Brady) \\ Globorotalia limbata (Fornasini) \\ Globorotalia menardii (Parker, Jones, \& Brady) \\ Neogloboquadrina dutertrei (d'Orbigny) \\ Neogloboquadrina humerosa (Takayanagi \& Saito) \\ Neogloboquadrina pachyderma (Ehrenberg) \\ Orbulina universa d'Orbigny \\ Pulleniatina alicusps Carreño \\ Pulleniatina praecursor Banner \& Blow \\ Pulleniatina primalis s.l. Banner \& Blow \\ Sphaeroidinellopsis seminulina (Schwager)
}

\section{Calcareous Nannoplankton ${ }^{\mathrm{b}}$}

Braarudosphaera bigelowi (Gran \& Braarud)

Calcidiscus leptoporus (Murray \& Blackman)

Calcidiscus macintyeri (Bukry \& Bramlette)

Coccolithus carteri

Coccolithus eopelagicus (Bramlette \& Riedel)

Coccolithus pelagicus (Wallich)

Dictyococcites minutus Black

Heliosphaera carteri (Wallich)

Heliosphaera selli Bukry \& Bramlette

Pontosphaera spp.

Reticulofenestra haqi Backman

Reticulofenestra minutula (Gartner)

Thoracosphaera spp.

\footnotetext{
a Identified in samples collected from the $30 \mathrm{~m}$ section of the Carmen Formation illustrated in Fig. 9 and in samples from correlative horizons in this unit exposed to the east of this section. Key foraminiferal taxa range through the sediments sampled, hence the zonal assignment encompasses the entire $30 \mathrm{~m}$ of section.

b Identified by Stanley Kling.
}

to the Carmen Formation as confirmed by application of modern planktonic biostratigraphy during this study.

Planktonic foraminifera are common to abundant in 13 samples collected from the lower portion of the marlstone unit northwest of Punta Perico (Fig. 9). Planktonic foraminifera commonly comprise $15-20 \%$ of the total benthic and planktonic foraminiferal populations in these samples. Because the biostratigraphically significant species of planktonic foraminifera range through much of the $30 \mathrm{~m}$ section of the marlstone unit illustrated in Fig. 9, a summary list of all species identified in this section is provided (Table 2). In addition, calcareous nannofossils were analyzed by Stanley Kling (1997, personal communication) in samples 6 and 7 of this same section, with species identified also listed in Table 2.

The studied planktonic foraminiferal assemblages are dominated by species of Globigerina, Globigerinoides, Globorotalia, Neogloboquadrina and Pulleniatina typical of a tropical surface water setting and similar to modern planktonic faunas inhabiting the southern Gulf of California today (Parker, 1973). Some samples contain significant numbers of Globigerina bulloides, presumably reflecting episodic upwelling and high productivity. Key planktonic foraminifera identified in the marlstone unit include Globigerinoides extremus, G. obliquus, Globorotalia limbata, Neogloboquadrina dutertrei, N. humerosa, Pulleniatina alicusps, $P$. praecursor, $P$. primalis s.l., and Sphaeroidinellopsis seminulina (Table 2). The co-occurrence of late forms of Pulleniatina primalis s.l. and $P$. praecursor together with specimens of the distinctive form $P$. alicuspis described from upper Pliocene deposits in the Gulf of California (Carreño, 1992) indicate an age no older than $3.5 \mathrm{Ma}$, following ranges and correlations presented by Keigwin (1976); Kennett and Srinivasan (1983), and Berggren et al. (1995). In addition, the co-occurrence of common specimens of Neogloboquadrina humerosa, rare specimens of $N$. dutertrei, and Sphaeroidinellopsis seminulina allow the fauna to be correlated with zone PL3 of Berggren et al. (1995), which places an upper limit on the age of these sediments of 3.1 Ma following correlations of Berggren et al. (1995).

An upper Pliocene age for the Carmen Formation sediments is also indicated by the character of the calcareous nannofossils identified in 
the marlstone unit (Table 2). According to Stanley Kling (1997, personal communication), the floras identified do not contain common and widespread early Pliocene forms such as Reticulofenestra pseudoumbilicata and Sphenolithus spp. suggesting that they are late rather than early Pliocene in age. Hence, the floras are tentatively assigned to calcareous nannofossil zone CN12 of Bukry (1973, 1975). The absence of the early Pliocene forms does not appear to be a preservational problem and they have been routinely reported to be present in lower Pliocene deposits elsewhere within the Gulf of California region (Aubry, 1979; Carreño, 1992; McDougall et al., 1999).

Finally, extinct species of benthic foraminifera also indicate a late Pliocene age for these sediments, and include Cassidulinella pliocenica and Amphistegina gibbosa. Cassidulinella pliocenica was originally described from upper Pliocene sediments of southern California and is a distinctive species with an apparently narrow stratigraphic range (Natland, 1940). Amphistegina gibbosa is a tropical reef dwelling species which is still living in the Atlantic-Caribbean province but apparently became extinct in the eastern Pacific Ocean in late Pliocene time ca. 2.5 Ma due to closure of the Isthmus of Panama and cooling water temperatures (Crouch and Poag, 1979). This littoral species is present in a number of the studied samples (Fig. 9B) and has been reported from Pliocene and upper Miocene age sediments elsewhere in the Gulf of California (McDougall et al., 1999). This species has most recently been reported in upper Pliocene sediments of the Loreto basin (Fig. 1B; Douglas et al., 1998a) where radiometric dating indicates these deposits range from ca. 2.6-1.97 Ma in age (Umhoefer et al., 1994).

\section{Structural analysis}

\subsection{Data}

We observe numerous features, all located near the eastern margin of the Pliocene section, that record synbasinal deformation during deposition. Several growth structures involve thickening of strata into the hangingwall of normal faults, and include: meter-scale soft-sediment faults in the north beach section (Fig. 5C); an intra-formational fault at north beach that has $\sim 10 \mathrm{~m}$ of throw and is overlain by unfaulted strata; and the keystone graben at the south end of the eastern fault (Figs. 2B, 3B and 7). Other evidence for soft-sediment deformation includes conglomerate clasts that have been dragged into plastic-style fault planes (Fig. 5C,D) and clastic sand dikes $\mathrm{mms}$ to $\mathrm{cms}$ wide that inject into fault planes and adjacent footwall deposits (Fig. 5D). We also have observed many mm- to $\mathrm{cm}$-wide deformation bands in Pliocene sandstones at north beach that are subparallel to soft-sediment faults and in some cases form web-like networks (e.g. above the hammer in Fig. 5C). Many soft-sediment deformation features at north beach are associated with small conjugate faults that commonly die out up section and are defined by thin clastic seams and deformation bands. Many of the observed small-scale deformation structures (including liquefaction features and associated deformation bands) are similar to features described in the Loreto basin by Zanchi (1991) and in unconsolidated Quaternary sediments on the northern California coast (Cashman and Cashman, 2000). Finally, the map pattern in Fig. 2B (eastern part) appears to require a buttress unconformity between the conglomerate-sandstone unit and overlying marlstone-mudstone unit, which suggests a phase of intrabasinal erosion related to deformation.

Several large normal and oblique-normal faults cut Miocene and Pliocene rocks in the Punta Perico area (Fig. 2B). These faults form two sets: one set that strikes N-NNE, and one that strikes NW (average $\sim 315^{\circ}$ ). The $\mathrm{N}$-striking fault that bounds the eastern margin of the Pliocene section has a minimum dip-slip separation of $1.5 \mathrm{~km}$ (Fig. 3B). A major NW-striking normal fault truncates the southwestern edge of the outcrop belt and appears to control the orientation of the shoreline on the SW edge of the peninsula (Fig. 2B). This fault has $\sim 650 \mathrm{~m}$ of stratigraphic throw, as determined from offset of the base of the marlstone-mudstone unit. Pliocene strata in the study area form a 2-km-wide, SE-dipping homocline (Figs. 2B and 3B). The strike of bedding is not parallel to that of the eastern basin-bounding fault, but instead strikes $\sim 25^{\circ}$ more easterly than the fault. The strike of bedding in Miocene volcanic rocks below and 


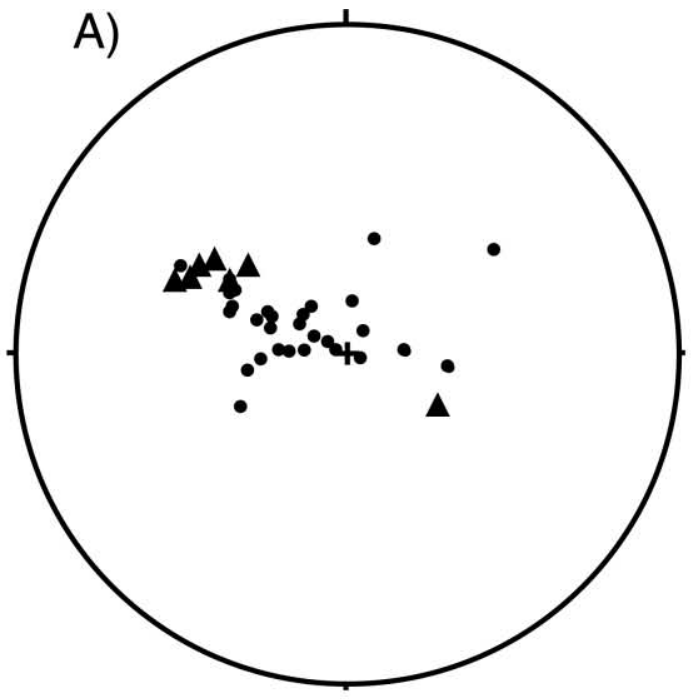

- = Pliocene bedding $(\mathrm{N}=28)$

$\Delta=$ Miocene bedding $(\mathrm{N}=7)$

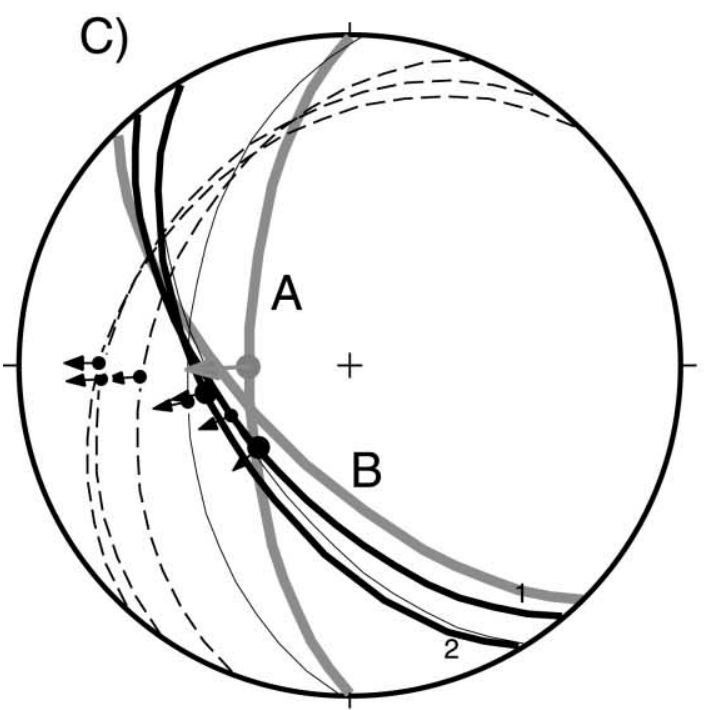

Faults in Pliocene Rocks:

thick black lines $=2$ major NW-striking faults thick gray line $=$ major fault at $E$ end of North Beach dashed lines $=3$ faults from within fault zone at $E$ end of North Beach

thin lines $=2$ secondary faults from south end of eastern basin-bounding fault

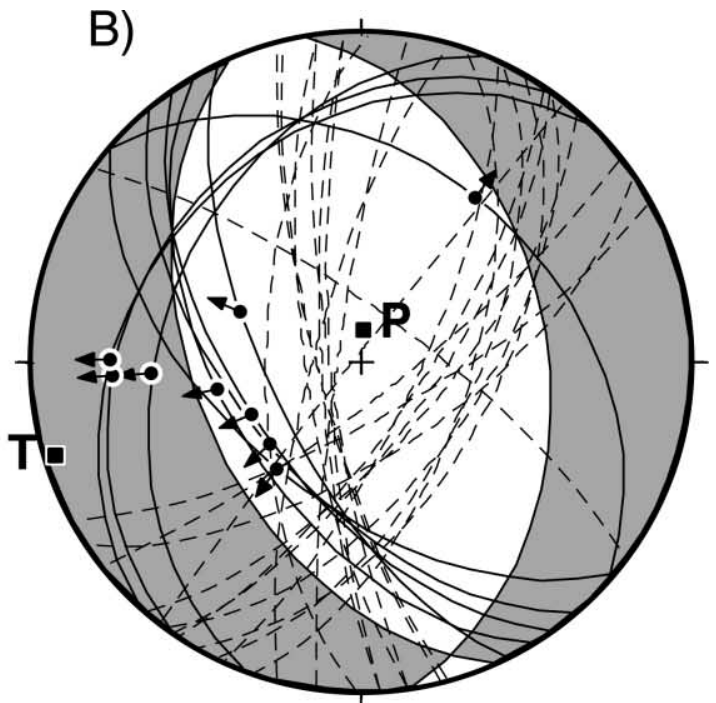

Faults in Pliocene strata: 7 with striae, 22 without striae

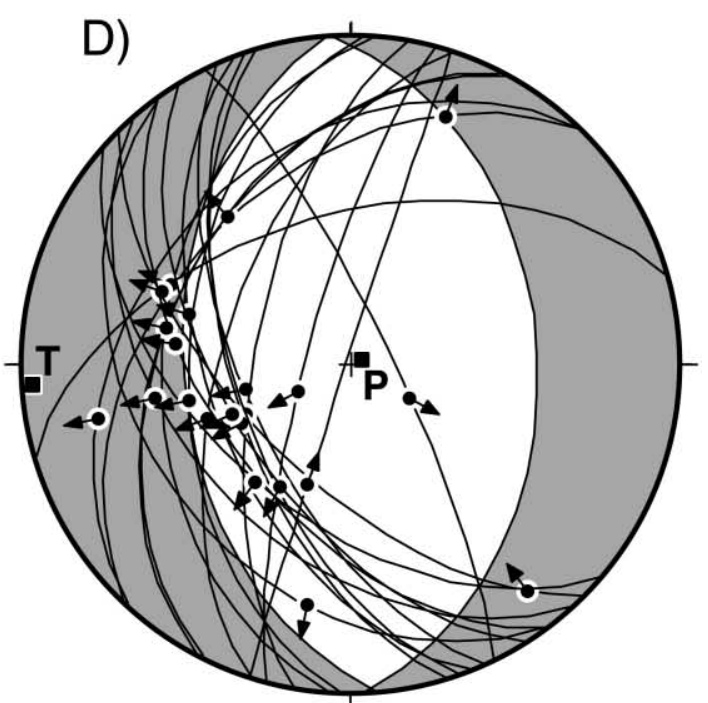

Faults in Miocene Rocks $(\mathrm{N}=22)$

Fig. 10. Lower hemisphere, equal-area stereonets showing the structural characteristics of bedding and faults in the Punta Perico area. (A) Poles to bedding for Miocene volcanic rocks and Pliocene sedimentary rocks. Miocene rocks dip consistently more steeply than the Pliocene strata, and dip direction is predominantly toward the SE. (B) and (C) Faults in Pliocene strata at north beach (NB) and elsewhere in the area. (D) Faults in Miocene volcanic rocks. 
adjacent to the contact with Pliocene strata is subparallel to that of the Pliocene rocks, but the average dip of bedding in the Miocene rocks is about $10^{\circ}$ steeper than in the Pliocene section (Figs. 3 and 10A).

Striations on the major faults and secondary faults within the major fault zones indicate that all of the faults are either pure normal faults or have a small component of dextral slip, indicating movement of their hangingwall to the $\mathrm{W}$ and SW (Fig. 10C). Secondary faults with observed striae strike NW to NNE and dip to the W (Fig. 10B,D). Striae on these faults indicate motion to the SW to WNW, with an average trend of $\sim 260^{\circ}$, similar to kinematics of the major faults. Faults without striae are common in the Pliocene section. Along the southern beach, the strike of unstriated faults is similar to that of striated faults, with dip directions varying from SW to WNW. Unstriated faults at north beach (NB, Fig. 2B) form two conjugate sets, one set that strikes $\mathrm{N}$ and dips steeply $\mathrm{W}$, and another that strikes NE and dips steeply to moderately to the SE (Fig. 10B, dashed lines).

\subsection{Interpretation}

Pliocene strata in the Punta Perico area record complex faulting that occurred during deposition of the upper part of the section. Most of the features that show soft-sediment deformation are located within $\sim 250 \mathrm{~m}$ of the large, $\mathrm{N}$-striking eastern normal fault, and there is abundant evidence that the upper part of the section was deposited during displacement on this fault. It is possible that the large eastern normal fault was active during deposition of the entire Pliocene section and acted as a basin-bounding border fault.

Fault-kinematic data in the Punta Perico area yield an average extension direction of west-southwest, intermediate between the late Miocene proto-gulf direction $\left(250^{\circ}\right)$ and modern $\left(280^{\circ}\right)$ extension direction determined in the Loreto region (Umhoefer and Stone, 1996; Umhoefer et al., 1997). The kinematics on major faults varies between southwest and westward movement of the hanging wall blocks (Fig. 10C), and the kinematics on secondary faults varies more widely but around the same directions (Fig. 10B,D). Rather than taking the average extension direction at face value, however, it appears that the $\mathrm{N}$-striking and $\mathrm{NW}$-striking faults make up two distinct fault populations that may record different stages of extensional strain. $\mathrm{N}$-striking normal faults are approximately parallel to late PlioceneQuaternary normal faults in the southeast Loreto basin (Umhoefer and Stone, 1996), and similarly are interpreted to record $\sim \mathrm{E}-\mathrm{W}$ extension. The NW-striking faults are more difficult to interpret and are discussed below.

NW-striking faults in the Punta Perico area could be reactivated proto-gulf (late Miocene) faults, since they strike within $\sim 10^{\circ}$ of typical proto-gulf normal faults (Umhoefer et al., 1997). However, their orientation is also very close to that of major transform faults in the Gulf of California, and the map pattern suggests that they cross-cut and are younger than the $\mathrm{N}$-striking eastern normal fault. Thus we believe that the NW-striking normal faults may reflect the modern state of stress and strain accumulating in the region. Although NW-striking faults in the gulf are generally expected to be strike-slip faults, the faults observed in this study consistently reveal down-dip lineations that indicate normal displacement. We suggest that normal offset on NW-striking faults could be the result of transform-normal extension as proposed by BenAvraham (1992) and Ben-Avraham and Zoback (1992). According to this model, large faults oriented parallel to major transforms experience both strikeslip and dip-slip movement, with normal displacement resulting from deflection of the stress field in the vicinity of weak faults where high shear stresses cannot be maintained (Ben-Avraham and Zoback, 1992). The weak-fault model is controversial (Scholz and Saucier, 1993), and it is beyond the scope of this paper to fully evaluate this problem.

Alternatively, the NW-striking faults may have been active concurrently with the large eastern normal fault, although we have no data or direct observations to support this interpretation. If the two fault sets were active concurrently, it could reflect a mixed mode of fault kinematics that existed during a transition in structural style from NE to $\mathrm{SW}$ extension to $\sim \mathrm{E}-\mathrm{W}$ extension in the gulf. However, this would imply a middle Pliocene timing of tectonic change, which is substantially later than the time (late Miocene to early Pliocene) when this transition is believed to have occurred in the region (Angelier et al., 1981; Stock and Hodges, 1989; Umhoefer and Stone, 1996). For 
this reason we favor the first interpretation, that the NW-striking normal faults represent modern strain accumulating in the area and probably are younger than the large $\mathrm{N}$-striking eastern normal fault. If Carmen Island has rotated substantially clockwise since middle Pliocene time, it would further suggest that the eastern normal fault may have originally formed as a NW-striking normal fault that later was rotated into its present position. This last idea is speculative and needs to be tested in future studies of paleomagnetism on the island.

Pliocene strata in the study area contain many characteristics of a half graben that formed adjacent to the eastern fault, but some aspects of the structure also indicate that it is not a simple half graben. The presence of two major sets of faults with different orientations and variable kinematics is not a simple half graben geometry. The dip direction of the thick homoclinal section is not perpendicular to either the eastern or the northern basin-bounding faults, and it also is not intermediate between the two sets of faults, which might be expected if both sets of faults were active during deposition. Instead, the beds dip to the southeast, oblique to the eastern fault and away from the NW-striking faults. The conjugate faults in the north beach section also do not have a simple orientation relative to the eastern fault, but instead define an oblique configuration in which the intersection of the two planes plunges moderately to the south (Fig. 10B). The orientation of the small conjugate faults is similar to that of faults which bound the keystone graben at the southern end of the eastern fault; this graben is defined by antithetic northeaststriking normal faults that dip southeast and truncate downward against the main, west-dipping eastern fault (Fig. 3B). The northeast strike of these faults is subparallel to the strike of bedding in the thick Pliocene section, and we infer that these faults may represent an adjustment in slip direction along the eastern fault, from west-directed extension to more west-northwest-east-southwest extension during evolution of the eastern fault zone.

\section{Discussion and conclusions}

Pliocene strata of the Carmen Formation at Punta Perico provide insights into the nature of marine sedimentation and deformation during the early stages of development of the Gulf of California. Below we integrate information about age, stratigraphic styles, thicknesses, and contact relationships to consider the possible regional significance of events recorded here. First, we can use the age of the marlstone unit $(\sim 3.5-3.1 \mathrm{Ma})$ and measured thickness of underlying conglomeratic units $(\sim 900 \mathrm{~m})$ to estimate a range of possible ages for the onset of marine deposition at Punta Perico. Although the lower conglomerate is not dated, we infer that the rate of sediment accumulation in a rift-controlled marine slope setting of this nature can be bracketed between about 0.2 and $1.0 \mathrm{~m} / \mathrm{ka}$, which yields a bracketing age estimate for the base of the section of between about 8 and $4 \mathrm{Ma}$ (late Miocene to early Pliocene). Although this value is under-constrained, it allows the basal unconformity to be placed in a regional context.

The major tectonic transition that took place in the southern gulf region during this time was the onset of strike-slip faulting and initial opening of the Gulf of California at $\sim 6 \mathrm{Ma}$ (Larson et al., 1968; Lonsdale, 1989). It is possible that this tectonic change caused widespread subsidence that led to submergence of the Comondú volcanic rocks below sea level and onset of marine deposition. Although we have not observed transgressive shoreline or shallow marine strata in the lower part of the section, the basal $\sim 20-30 \mathrm{~m}$ of the section are covered and may contain a thin interval of rocky shoreline and nearshore deposits. If present, the inferred transgressive deposits are overlain by a succession of coarse-grained slope conglomerates that displays remarkable thickness $(\sim 750 \mathrm{~m})$ and lack of interbedded fines. This appears to require that the subsidence event that initiated deposition at Perico was very rapid, causing an area that was previously eroding above sea level to be quickly transformed into a submarine slope without preserving a substantial thickness of deposits belonging to the intervening environments. This implied rapid rate of basin initiation supports the inference that the onset of sedimentation at Punta Perico may have been related to the tectonic transition at $\sim 6 \mathrm{Ma}$ that caused initial opening of the Gulf of California. Alternatively, deposition of the thick lower conglomerate units may have begun during late Miocene proto-gulf extension (Stock and Hodges, 1989), with deposition continuing into early Pliocene time. We presently do 
not have sufficient data to distinguish between these two possibilities.

The next significant change in the section occurs at the unconformity between the conglomerate-sandstone unit and overlying foram-rich marlstonemudstone. This contact records a period of submarine erosion followed by pelagic sedimentation in a bathyal marine setting that was nearly isolated from detrital input, in sharp contrast to conditions represented by the underlying and overlying conglomeratic units. Our field data show that the large eastern normal fault was active during deposition of the upper four units in the study area, and it seems likely that the unconformity at the base of the marlstone unit is related to this phase of fault slip and syn-basinal deformation. The switch to sediment-starved conditions represented by the marlstone may have resulted from basin reorganization and construction of structural barriers in a deforming slope, which could have blocked input of clastic material for a period of time. A tectonically active and unstable setting is further suggested by: (1) catastrophic emplacement of dacitic submarine avalanches and boulder beds at the end of the starved-basin phase and (2) apparently rapid uplift and transition to shelfal carbonates and reworked gravels represented by the upper unit. The biostratigraphy of forams and calcareous nanoplankton yields an age of $\sim 3.5-3.1 \mathrm{Ma}$ for the marlstone unit. Although we cannot prove a direct link, we hypothesize that intrabasinal deformation and rapid uplift of the sea floor were controlled by changes in local faulting patterns related to a regional tectonic transition, from early Pliocene oblique rifting to the modern system of large transform faults and small oceanic spreading centers, at approximately 3.5 Ma (Lonsdale, 1989). This may also coincide with intiation of the Loreto fault and Loreto basin at about 3.5-3.6 Ma (Dorsey and Umhoefer, 2000).

Finally, we consider the strain patterns represented by fault-kinematic data presented above. The data give mixed results in which both $\mathrm{NW}$ - and $\mathrm{N}$-striking major faults have dominantly down-dip striae, and thus appear to record both NE-SW and E-W extension (Fig. 10). The E-W direction resembles that of Plio-Pleistocene extension associated with the modern phase of dextral shear and oblique rifting in the gulf (Angelier et al., 1981; Stock and Hodges, 1989; Umhoefer and Stone, 1996). NE-SW extension is commonly attributed to late Miocene proto-gulf extension, but in the Punta Perico area the map pattern suggests that the NW-striking normal faults may be younger than the large $\mathrm{N}$-striking fault at the eastern boundary of the Pliocene section. We know that the eastern normal fault was active during deposition of the upper part of the section, and it's possible that the NW-striking faults also are synbasinal, although we have no direct evidence for that. Both sets of faults cut the marlstone unit. With these constraints and uncertainties in mind, we suggest that the NW-striking normal faults may reflect the modern, active strain field, and that large normal displacements have occurred on NW-striking faults which are expected to be strike-slip faults. This can potentially be explained as a product of transform-normal extension that results from slip on a relatively weak fault embedded in a relatively strong crust (Ben-Avraham and Zoback, 1992), but this idea is speculative and remains untested.

\section{Acknowledgements}

This work was supported by a grant from the National Science Foundation (NSF no. EAR9526506). We are grateful to Benito Bermuves, Director of the Parque Marino Nacional Bahia de Loreto, for granting us permission to study the geology of Carmen Island and helping coordinate the logistics of our access to the island. Paul Renne provided an ${ }^{40} \mathrm{Ar}-{ }^{39} \mathrm{Ar}$ date on the dacite unit. Tobias Schwennicke and Cathy Busby are thanked for their thoughtful and constructive reviews of this paper.

\section{References}

Anderson, C.A., 1950. Geology of islands and neighboring land areas. 1940 E.W. Scripps cruise to the Gulf Of California. Geol. Soc. Am. Mem. 43 (1), iii-53.

Angelier, J., Colletta, B., Chorowicz, J., Ortlieb, L., Rangin, C., 1981. Fault tectonics of the Baja California Peninsula and the opening of the Sea of Cortez. Mexico. J. Struct. Geol. 3, 347-357.

Aubry, M.-P., 1979. Calcareous nannofossil biostratigraphy. Leg 64. Init. Rep. Deep Sea Drilling Proj. 64, 955-972.

Bandy, O.L., 1961. Distribution of foraminifera, radiolaria, and diatoms in the Gulf of California. Micropaleontol. 7, 1-26.

Bandy, O.L., Arnal, R.E., 1957. Distribution of Recent foraminifera 
off the west coast of Central America. Am. Assoc. Pet. Geol. Bull. 41, 2037-2053.

Ben-Avraham, Z., 1992. Development of asymmetric basins along continental transform faults. Tectonophysics 215, 209-220.

Ben-Avraham, Z., Zoback, M.D., 1992. Transform-normal extension and asymmetric basins; an alternative to pull-apart models. Geology 20, 423-426.

Berggren, W.A., Hilgen, F.J., Langereis, C.G., Kent, D.V., Obradovicxh, J.D., Raffi, I., Raymo, M.E., Shackleton, N.J., 1995. Late Neogene chronology: new perspectives in high resolution stratigraphy. Geol. Soc. Am. Bull. 107, 1272-1287.

Berggren, W.A., Kent, D.V., Swisher III, C.C., Aubry, M.-P., 1995. A revised Cenozoic chronology and chronostratigraphy. Soc. Econ. Paleontol. Mineral. Spec. Publ. 54, 129-212.

Boehm, M.C., 1984. An overview of the lithostratigraphy, biostratigraphy, and paleoenvironments of the late Neogene San Felipe marine sequence, Baja California, Mexico. In: Frizzell Jr, V.A. (Ed.), Geology of Baja California Peninsula. Field Trip Guidebook. Pac. Sect., Soc. Econ. Paleontol. Mineral., 39. pp. 253-265.

Brenner, G.J., 1962. A zoogeographic analysis of some shallow water foraminifera in the Gulf of California. Bull. Am. Mus. Nat. Hist. 123, 249-298.

Bukry, D., 1973. Low-latitude coccolith biostratigraphic zonation. Init. Rep. Deep Sea Drilling Proj. 15, 127-149.

Bukry, D., 1975. Coccolith and silicoflagellate stratigraphy, northwestern Pacific Ocean, Deep Sea Drilling Project Leg 32. Init. Rep. Deep Sea Drilling Proj. 32, 677-701.

Carreño, A.L., 1992. Calcareous Neogene microfossils of Baja California Sur, Mexico. Universidad National Autonoma de Mexico, Instituto de Geologia Paleontologia Mexicana 59, $1-93$.

Cashman, S.M., Cashman, K.V., 2000. Cataclasis and deformationband formation in unconsolidated marine terrace sand, Humboldt County, California. Geology 28, 111-114.

Crouch, R.W., Poag, C.W., 1979. Amphistegina gibbosa d'Orbigny from the California borderlands: the Caribbean connection. J. Foram. Res. 9, 85-105.

Curray, J.R., Moore, D.G., 1984. Geologic history of the mouth of the Gulf of California. In: Crouch, J.K., Bachman, S.B. (Eds.), Tectonics and Sedimentation along the California Margin. Field Trip Guidebook. Pac. Sect. Soc. Econ. Paleontol. Mineral., 38. pp. 17-35.

DeMets, C., 1995. A reappraisal of seafloor spreading lineations in the Gulf of California; implications for the transfer of Baja California to the Pacific Plate and estimates of Pacific-North America motion. Geoph. Res. Let. 22, 3545-3548.

DeMets, C., Gordon, R.G., Argus, D.F., Stein, S., 1990. Current plate motions. Geoph. J. Internat. 101, 425-478.

Dorsey, R.J., Stone, K.A., Umhoefer, P.J., 1997. Stratigraphy, sedimentology, and tectonic development of the southeastern Loreto basin, Baja California Sur, Mexico. In: Johnson, M.E., Ledesma-Vasquez, J. (Eds.), Pliocene Carbonates and Related Facies Flanking the Gulf of California, Baja California Sur, Mexico. Geol. Soc. Am. Spec. Paper 318, pp. 83-109.

Dorsey, R.J., Kidwell, S.M., 1999. Mixed carbonate-siliciclastic sedimentation on a tectonically active margin: Example from the Pliocene of Baja California Sur, Mexico. Geology 27, 935-938.

Dorsey, R.J., Umhoefer, P.J., 2000. Tectonic and eustatic controls on sequence stratigraphy of the Pliocene Loreto basin, Baja California Sur, Mexico. Geol. Soc. Am. Bull. 112, 177-199.

Douglas, R.G., Arreola-Hernandez, J.F., Nava-Sanchez, E., Gorsline, D., 1998a. Depositional biofacies in the late Pliocene Loreto basin. Gulf of California. EOS, Trans., Am. Geoph. Union 79, F514.

Douglas, R.G., DeDiego, T., Gorsline, D., Nava-Sanchez, E., 1998b. Modern 'black shales' in the Gulf of California. Geol. Soc. Am. Abstr. with Progr. 30, A55.

Durham, J.W., 1950. Megascopic paleontology and marine stratigraphy. E.W. Scripps cruise to the Gulf of California. Geol. Soc. Am. Mem. 43 (II), 216.

Golik, A., Phleger, F., 1977. Benthonic foraminifera from the Gulf of Panama. J. Foram. Res. 7, 83-99.

Hampton, M.A., 1972. The role of subaqueous debris flow in generating turbidity currents. J. Sediment. Petrol. 42, 775-793.

Hampton, M.A., Lee, H.J., Locat, J., 1996. Submarine landslides. Reviews of Geophysics 34, 33-59.

Hausback, B.P., 1984. Cenozoic volcanic and tectonic evolution of Baja California, Mexico. In: Frizzell Jr, V.A. (Ed.), Geology of Baja California Peninsula. Field Trip Guidebook. Pac. Sect., Soc. Econ. Paleontol. Mineral., 39, pp. 219-236.

Hein, F.J., Walker, R.G., 1982. The Cambro-Ordovician Cap Enrage Formation, Quebec, Canada: conglomeratic deposits of a braided submarine channel with terraces. Sedimentology 29, 309-329.

Ingle Jr, J.C., 1974. Paleobathymetric history of Neogene marine sediments, northern Gulf of California. In: Gastil, G., Lillegraven, J. (Eds.), Guidebook to the Geology of Peninsular California. Pac. Sect. Soc. Econ. Paleontol. Mineral., pp. 121-138.

Ingle Jr, J.C., 1980. Cenozoic paleobathymetry and depositional history of selected sequences within the Southern California continental borderland. In: Sliter, W.V. (Ed.), Studies in Marine Micropaleontology and Paleoecology: a Memorial Volume to Orville L. Bandy. Spec. Pub., 19. Cushman Foundation for Foraminiferal Research, pp. 163-195.

Ingle, J.C., Keller, G., 1980. Benthic foraminiferal biofacies of the eastern Pacific margin between $40^{\circ} \mathrm{S}$ and $32^{\circ} \mathrm{N}$. In: Field, M., Bouma, A.H., Colburn, I.P., Douglas, R.G., Ingle, J.C. (Eds.), Quaternary Depositional Environments of the Pacific Coast. Pac. Sect. Soc. Econ. Paleontol. Mineral., Pacific Coast Paleogeography Symposium 4, pp. 341-355.

Keigwin Jr, L.D., 1976. Late Cenozoic planktonic foraminiferal biostratigraphy of the Panama basin. Micropaleontology 22, 419-442.

Kennett, J.P., Srinivasan, M.S., 1983. Neogene Planktonic Foraminifera. Hutchison Ross Publ. Co, Stroudsburg, p. 265.

Lankford, R.R., Phleger, F.B., 1973. Foraminifera from the nearshore turbulent zone, western North America. J. Foram. Res. 3, 101-132.

Larson, R.L., Menard, H.W., Smith, S.M., 1968. Gulf of California: A result of ocean-floor spreading and transform faulting. Science 161, 781-784. 
Lonsdale, P., 1989. Geology and tectonic history of the Gulf of California. In: Winterer, E.L. (Ed.), The Eastern Pacific Ocean and Hawaii. Boulder, Colorado, Geol. Soc. Am., Geology of North America, N, pp. 499-521.

Lowe, D.R., 1982. Sediment gravity flows: II. Depositional models with special reference to the deposits of high-density turbidity currents. J. Sediment. Petrol. 52, 279-297.

McCloy, C., Ingle, J.C., Barron, J.A., 1988. Neogene stratigraphy, foraminifera, diatoms, and depositional history of Maria Madre Island, Mexico: evidence of early Neogene marine conditions in the southern Gulf of California. Mar. Micropaleontol. 13, 193-212.

McDougall, K., Poore, R.Z., Matti, J., 1999. Age and paleoenvironment of the Imperial Formation near San Gorgonio Pass, southern California. J. Foram. Res. 29, 1-25.

McDougall, K., 1985. Miocene to Pleistocene benthic foraminifers and paleoceanography of the Middle America slope. Deep Sea Drilling Project Leg 84. Init. Rep. Deep Sea Drilling Proj LXXXIV, 363-418.

Moore, D.G., Buffington, E.C., 1968. Transform faulting and growth of the Gulf of California since late Pliocene. Science 161, 1238-1241.

Mulder, T., Cochonat, P., 1996. Classification of offshore mass movements. J. Sediment. Res. 66, 43-57.

Natland, M.N., 1940. New genus of foraminifera from the latter Tertiary of California. J. Paleontol. 14, 570.

Natland, M.L., 1950. Report on the Pleistocene and Pliocene Foraminifera. E.W. Scripps cruise to the Gulf Of California. Geol. Soc. Am. Mem. 43 (4), 1-55.

Nemec, W., 1990. Aspects of sediment movement on steep delta slopes. In: Colella, A., Prior, D.B. (Eds.), Coarse-Grained Deltas. Int. Assoc. Sedimentol. Spec. Publ. 10, pp. 29-73.

Nemec, W., Steel, R.J., 1984. Alluvial and coastal conglomerates; their significant features and some comments on gravelly mass-flow deposits. In: Koster, E.H., Steel, R.J. (Eds.), Sedimentology of Gravels and Conglomerates. Can. Soc. Petr. Geol., Mem. 10, pp. 1-31.

Parker, F.L., 1973. Living planktonic foraminifera from the Gulf of California. J. Foram. Res. 3, 70-77.

Phleger, F.B., 1964. Patterns of living benthonic foraminifera, Gulf of California. In: van Andel, Tj.H., Shor, G.G. (Eds.), Marine Geology of the Gulf of California. Am. Assoc. Petrol. Geol., Mem. 3, pp. 377-394.

Resig, J.M., 1981. Biogeography of benthic foraminifera of the northern Nazca plate and adjacent continental margin. In: Kulm, L.D., Dymond, J., Basch, J., Hussong, D.M. (Eds.), Nasca Plate: Crustal Formation and Andean Convergence. Geol. Soc. Am., Mem. 154, pp. 619-666.
Sawlan, M.G., 1991. Magmatic evolution of the Gulf of California rift. In: Dauphin, J.P., Simoneit, B.R.T. (Eds.), The Gulf and Peninsular Province of the Californias. Am. Asso. Petrol. Geol., Mem. 47, pp. 301-375.

Scholz, C.H., Saucier, F.J., 1993. What do the Cajon Pass stress measurements say about stress on the San Andreas Fault? Comment on: In situ stress measurements to $3.5 \mathrm{~km}$ depth in the Cajon Pass scientific research borehole; implications for the mechanics of crustal faulting. J. Geophys. Res. 98, 17,86717,873 .

Smith, P.B., 1963. Quantitative and qualitative analysis of the family Bolivinidae. U.S. Geol. Survey, Prof. Paper 429, A1-A38.

Smith, P.B., 1964. Ecology of benthonic species. U.S. Geol. Survey, Prof. Paper 429, B1-B55.

Stock, J.M., Hodges, K.V., 1989. Pre-Pliocene extension around the Gulf of California and the transfer of Baja California to the Pacific plate: Tectonics 8, 99-115.

Streeter, S.S., 1972. Living benthonic foraminifera of the Gulf of California, a factor analysis of Phleger's (1964) data. Micropaleontology 18, 64-73.

Umhoefer, P.J., Dorsey, R.J., Renne, P.R., 1994. Tectonics of the Pliocene Loreto basin, Baja California Sur, Mexico, and evolution of the Gulf of California. Geology 22, 649-652.

Umhoefer, P.J., Stone, K.A., 1996. Description and kinematics of the SE Loreto basin fault array, Baja California Sur, Mexico: a positive field test of oblique-rift models. J. Struct. Geol. 18, 595-614.

Umhoefer, P.J., Dorsey, R.J., 1997. Translation of terranes: Lessons from central Baja California, Mexico. Geology 25, 1007-1010.

Umhoefer, P.J., Mayer, L., Dorsey, R.J., 1997. Rift segmentation on the margin of the Gulf of California near Loreto, Baja California peninsula, Mexico. Geol. Soc. Am. Abstr. Progr. 29, A481.

Walker, R.G., 1975. Generalized facies models for resedimented conglomerates of turbidite association. Geol. Soc. Am. Bull. 86, 737-748.

Walker, R.G., 1977. Deposition of upper Mesozoic resedimented conglomerates and associated turbidites in southwestern Oregon. Geol. Soc. Am. Bull. 88, 273-285.

Winn Jr, R.D., Dott Jr, R.H., 1979. Deep-water fan-channel conglomerates of Late Cretaceous age, southern Chile. Sedimentology 26, 203-228.

Zanchi, A., 1991. Tectonic and liquefaction structures in the Loreto basin, Baja California (Mexico): synsedimentary deformation along a fossil fault plane. Geodyn. Acta 5, 187-202.

Zanchi, A., 1994. The opening of the Gulf of California near Loreto, Baja California, Mexico: from basin and range extension to transtentional tectonics. J. Struct. Geol., v. 16, 1619-1639. 